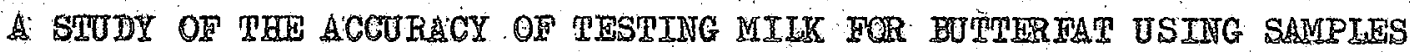
WITH AND WITHOOT CHEMTCAL PRESGRVATIVES

国

RaIp Ro: Taylor

D. Thesi Srbmitted to the Faculty of the DERPARTNI WNT OF DAIRY SCIENGE

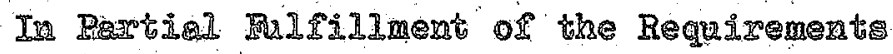

gor the Degres of

MASTHE OF SCIEHCE

In the Graduate College

UNIVERSITY OR ARIZONA 


\section{ACENOH LEDGEMENTS}

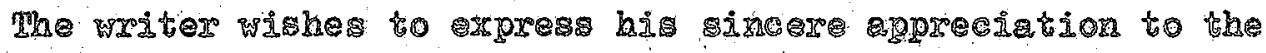

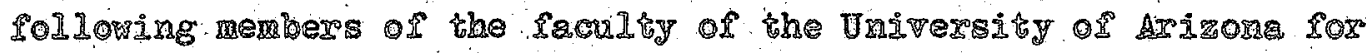

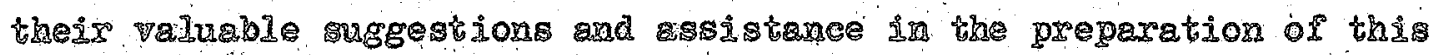

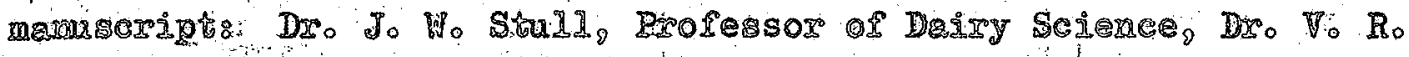

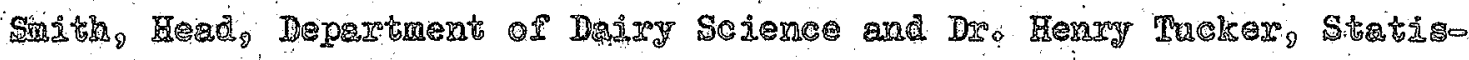

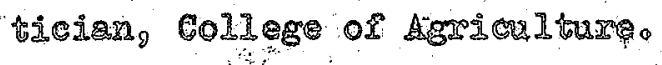

The cooperition of Shanxodk Dairy in the collection of the samo i...

ples was greatiy appreotated.

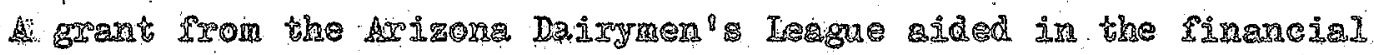

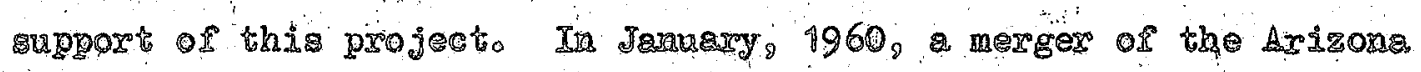

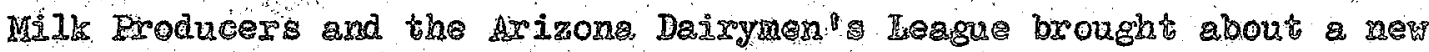

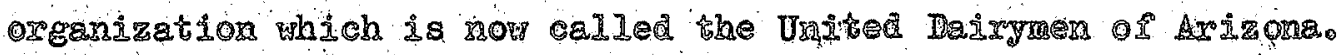




\section{STATEMENT BY ADTHOR}

This thesis has been abmitted in partial fulfillment of requirements for an advanced degree at the University of Arizona and is deposited in the University Library to be made available to borrowers under the rules of the library.

Brief quotations from this thesis are allowable without apecial permission, provided that accurate acknowledgement of source is made. Requests of permission for extended quotation from or reproduction of this manuscript in whole or in part may be granted by the head of the major department or the Dean of Graduate College when in their fudgement the proposed use of the material is in the interests of scholarship. In all other instances, however, permission must be obtalned from the author.

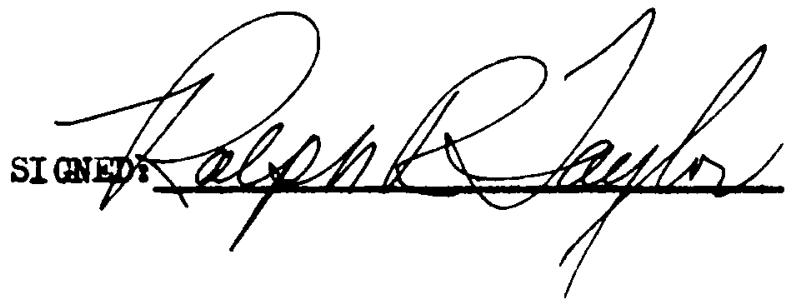

APFROVAL BY TEESIS DIRECTCR

This thesis has been approved on the date shown below:

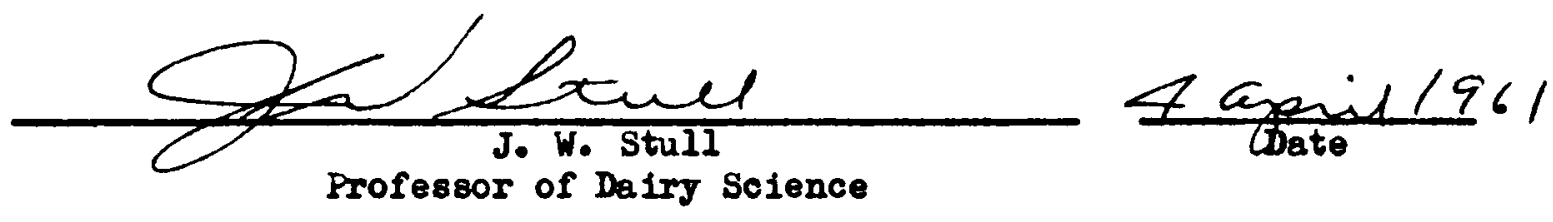




\section{TABLE OT CONTENTS}

CEAPYIR

PAGE

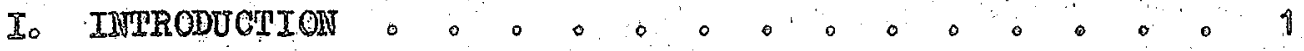

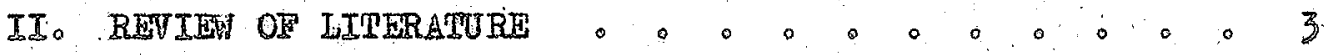

III. PROCEDURE 0.0 .

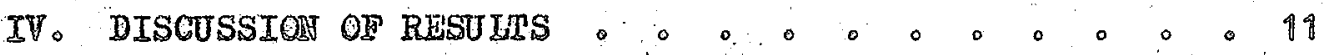

Vo CONCURSTONS

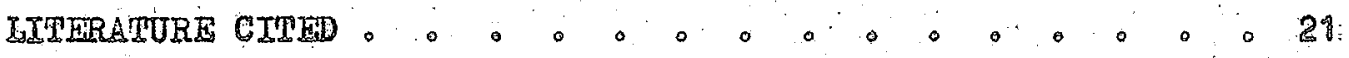

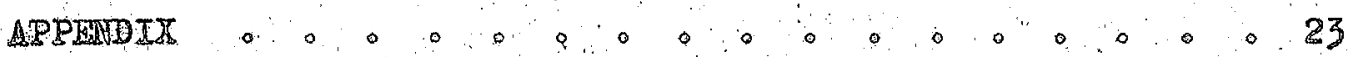




\section{IIST OF TSABLES}

\section{TABLE}

PAGE

Io Arerage Percent Buter fat for Poriolie Samping

Daily Sampling and Composite Smpling With and

Without Preservatives

or o. 0 o 0


Ged I

IDSTRODECTIOR

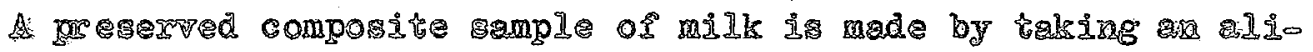

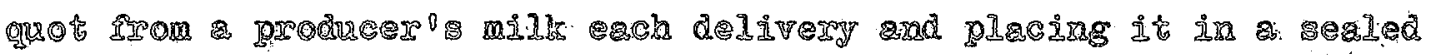

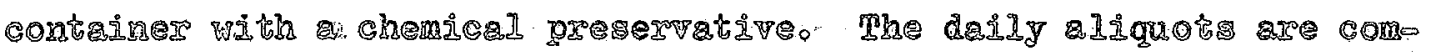

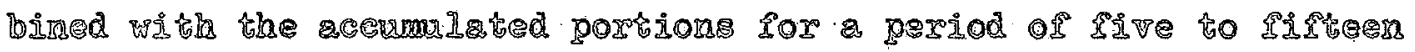

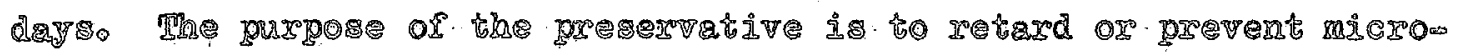

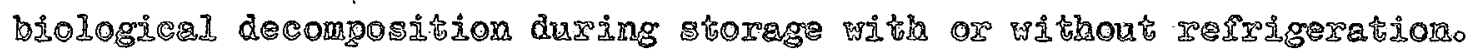

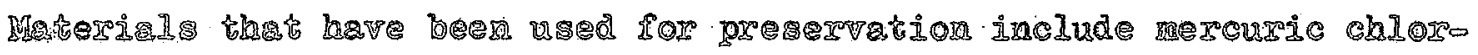

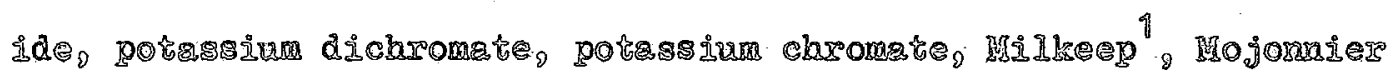

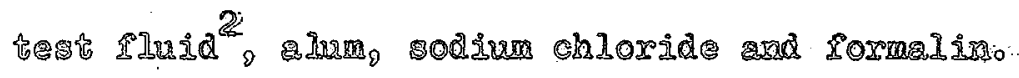

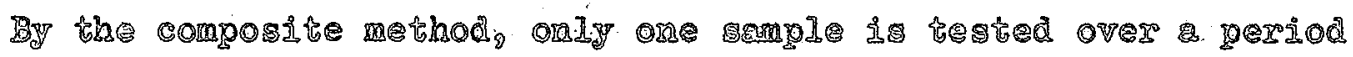

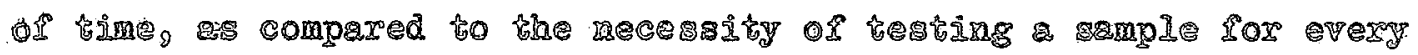

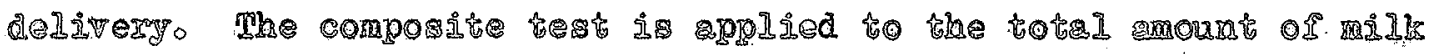

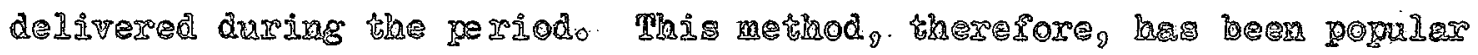

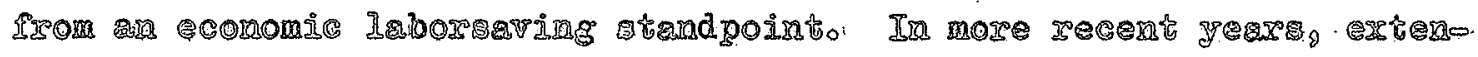

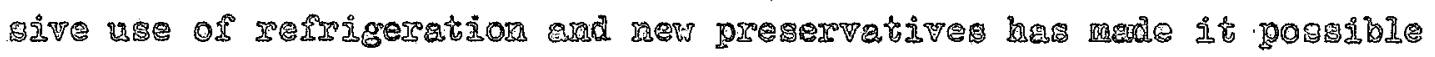

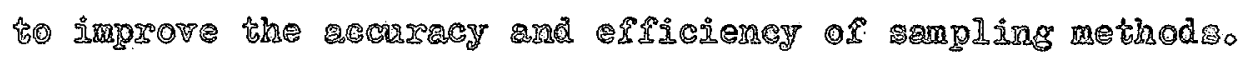

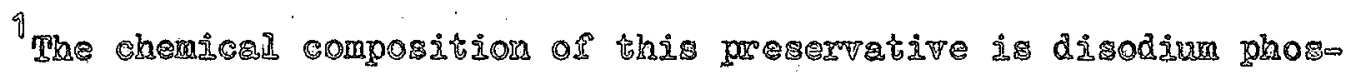

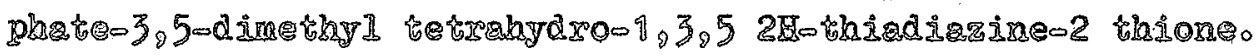

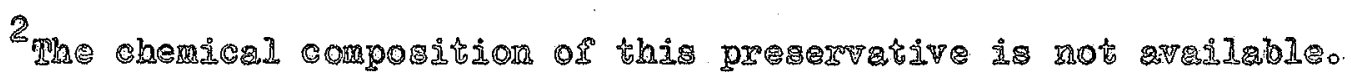




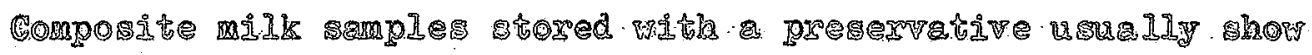

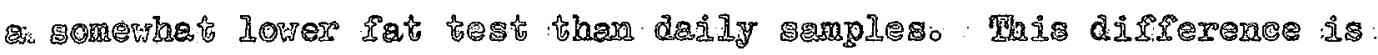

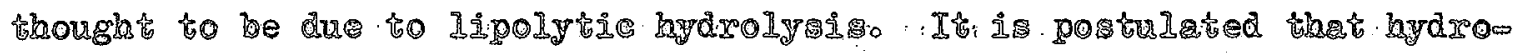

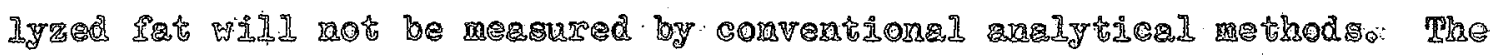

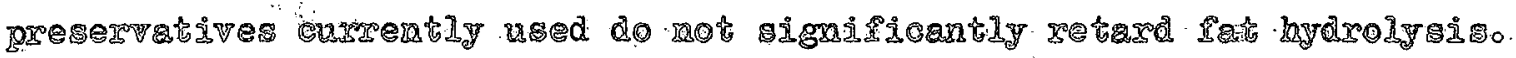

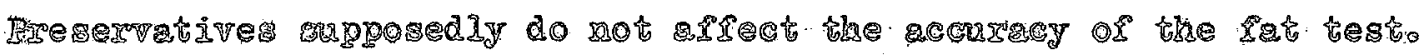

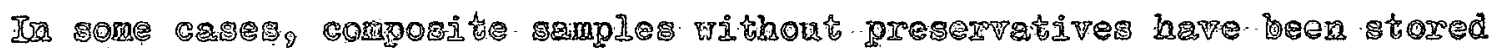
Wh

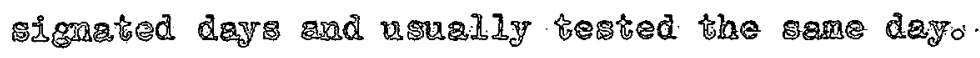

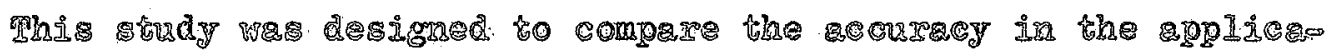

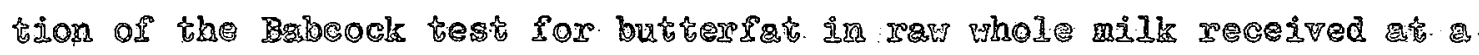

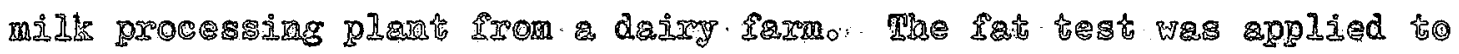
composithe samples with ad vithout added preservatives and conpared

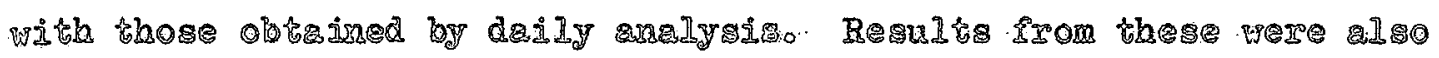

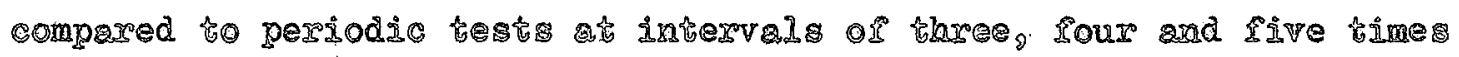
pers mosibro 


\section{CHAPTER II}

\section{REVIEW OF LITERATWRE}

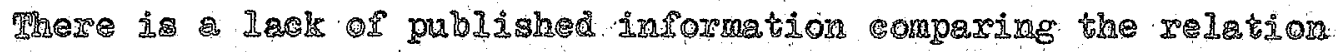

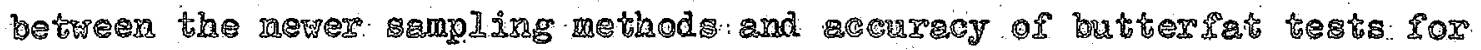

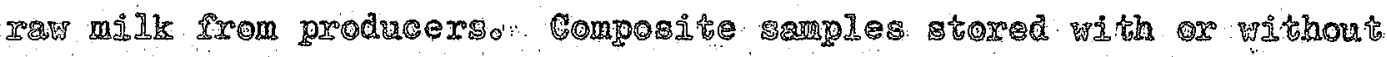

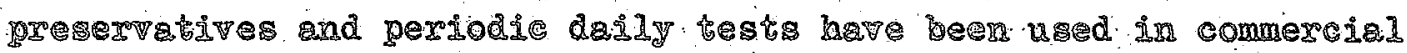

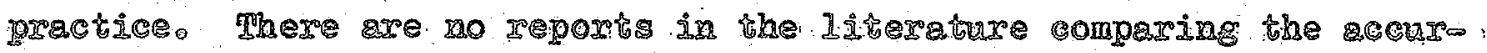

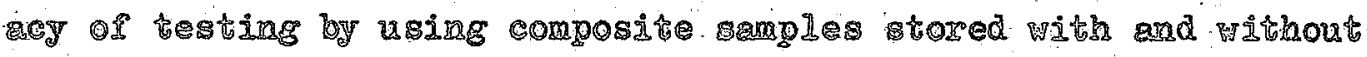
preservatives and periodic testio:

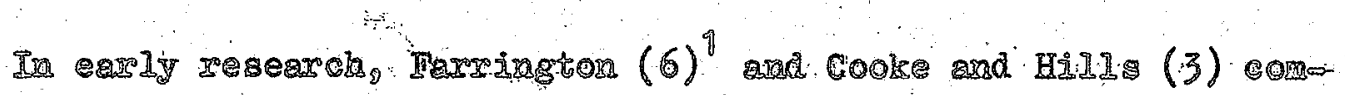

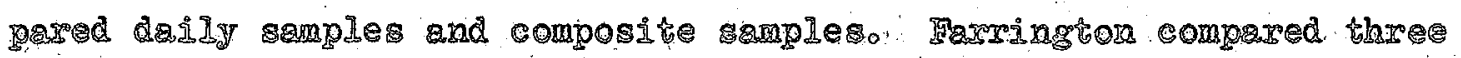

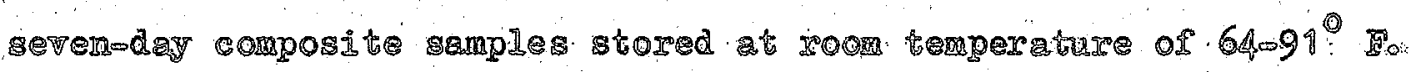
with daily sanpleso. The first composte sample was me from aliguot

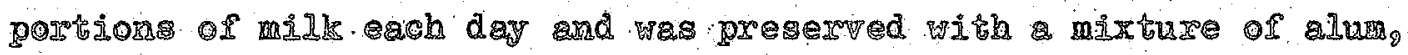
mexcurro chioride and table salto. The second sample contained a con. stan polume of mik taken each day and used the same preservative. The hird composite semple algo contained a constant volume of milk

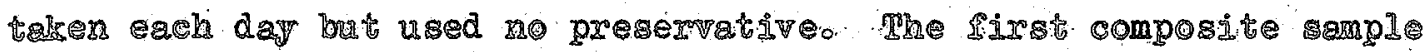
tested $30.93 \%$, the second $3096 \%$, the third $3.95 \%$ and the daily samples

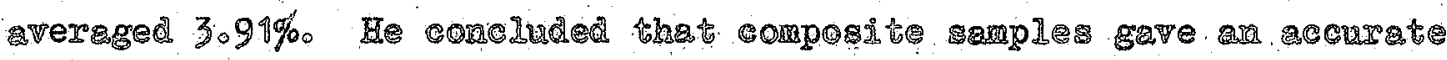

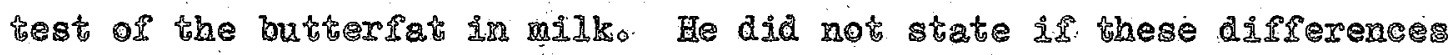

The rumbers in parentinesi refer to litergure cited. 


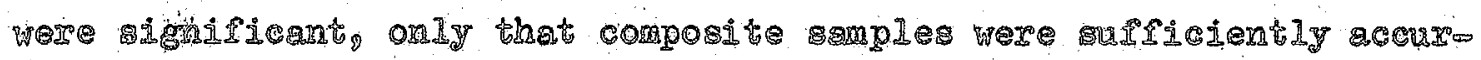
ate。 Cooke and Hills compared the tests Irom periodic samples taken

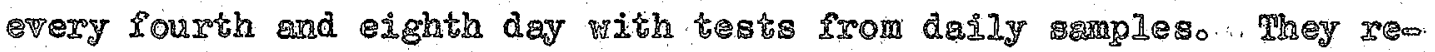
ported that there was less variability in sapliag every rourch day

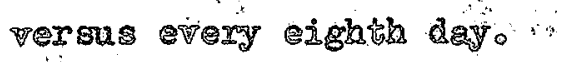

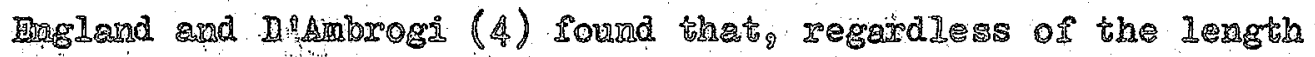
of time stored (7o15 day ), temperature of storage $\left(45-100^{\circ}\right.$ Wo or the

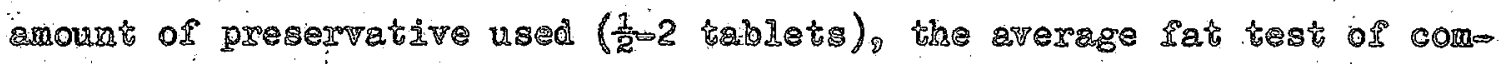

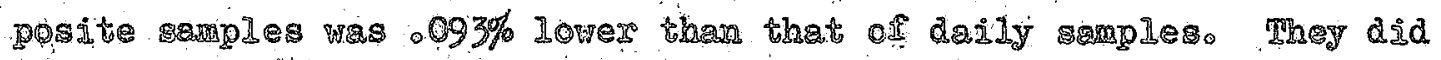

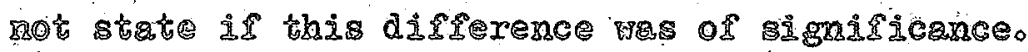

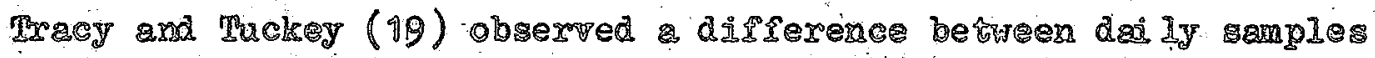

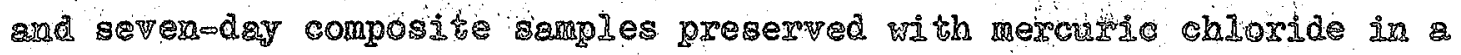

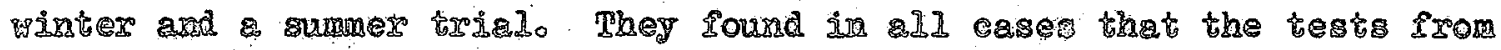

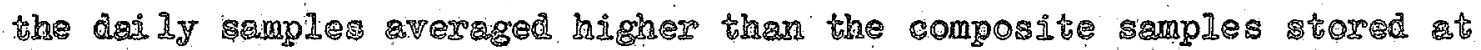
$40^{\circ}$ I. In the winter trial (divided in tho pasta) 0 the testa from the daily amples aperaged $006 \%$ wigner than the composite samples an the

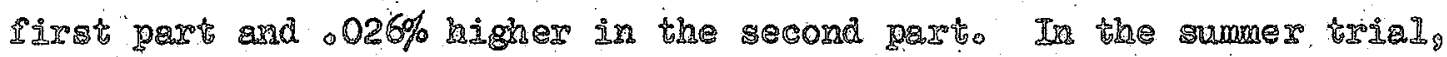
the daily gmples arerged.020\% higher than the composite samples. mhey concluded that ${ }^{15}$ inests on composite samples propexiy taken and stored would give an accurate mesurement of the fat contert of milk: Wilster and Roubichans (20) fowad that testí from rive, seven and fiftermoday composite amples preserved with mercuric chloride

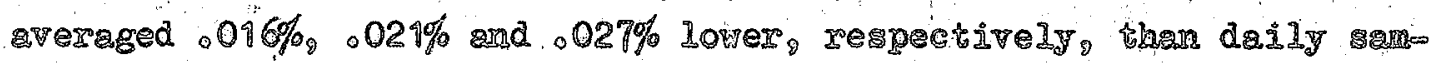
ples. They stated that these valus were mot gigniricanto The composite gam les vere tored $35-40^{\circ}$. 


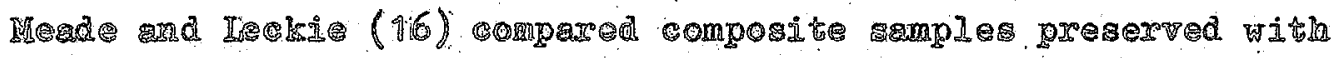

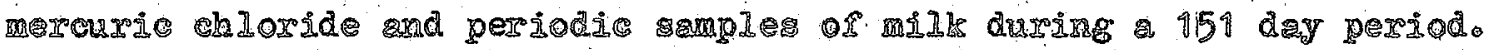
Three preserved composite

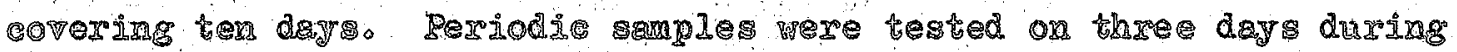

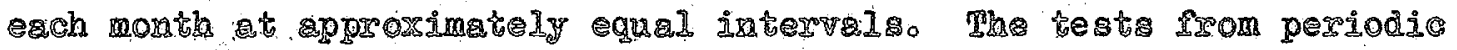

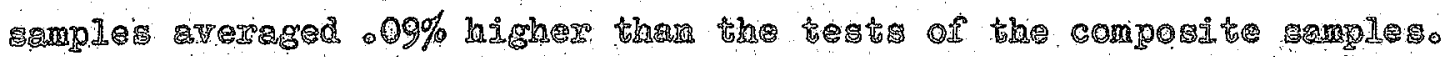

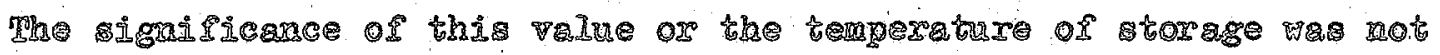

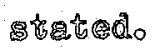

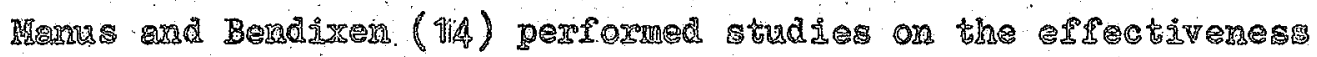

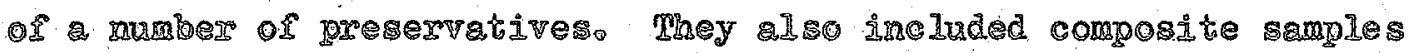

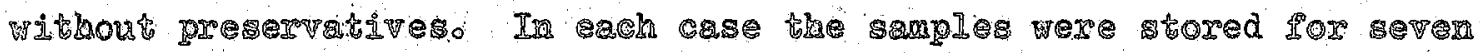
days at $35-38^{\circ}$ To. They conchuded that the reduction in iat test appeared

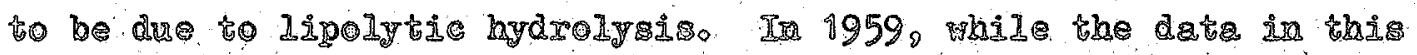

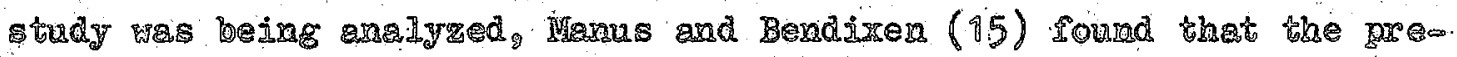

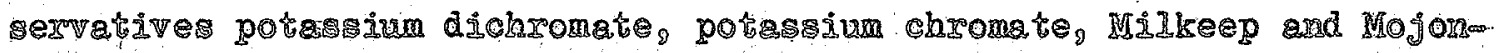

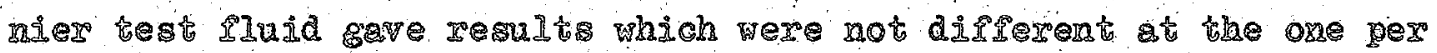

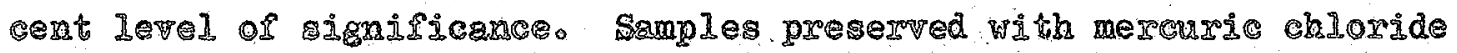

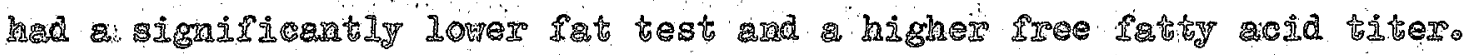
Whe amples were stored at $35 \times 38^{\circ}$. For one to two wereks.

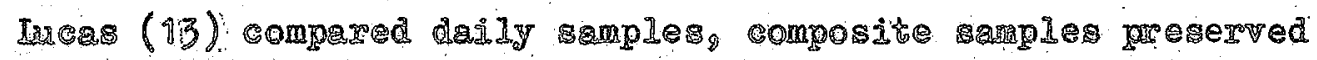

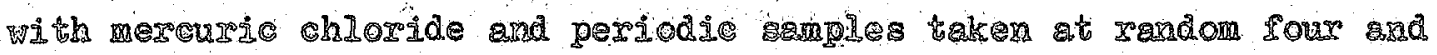

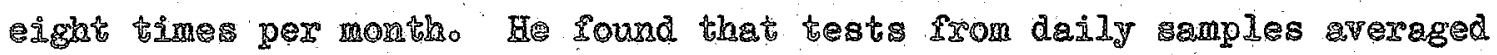
- $11 \%$ higher thara preserved composite samples. He did not indicate if this value was signiricant There wa no mignican difference betheer the test of periodic smples taken ejght times per mon and 
daily amples. Ee stated that periodio smples taken four times per morh showed variators great mongh to digeredit the method.

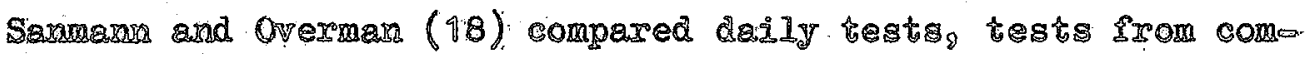

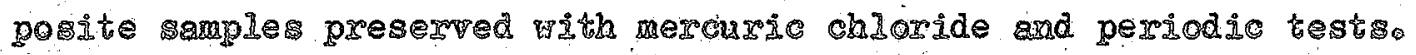
They coneluded that "ricomposite saples properly taken axd stored would

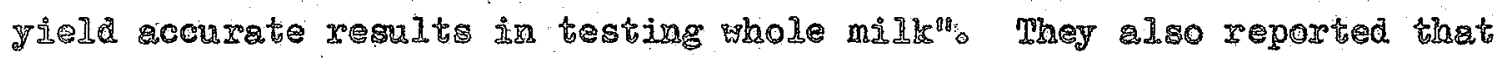
the average for Sive onoday test taken at equal Intervals during the month gave a closex approximation to the the average fat content of min then the average of four testso They fajled to state the temera thure at wion the composite samples were stored.

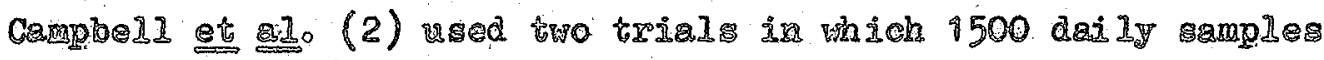

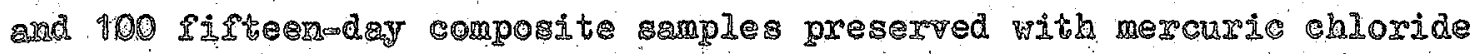
were tested. They fownd the testr srom daily samples averaged .03\% higher in the rixst tried ard o01\% higher in the second trial then

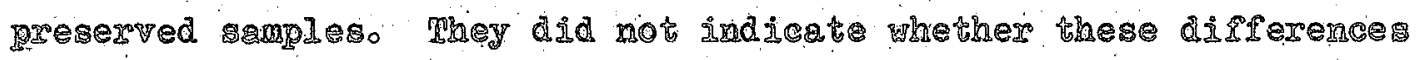
were significant or the tomperature at which the composite samplea were stored。

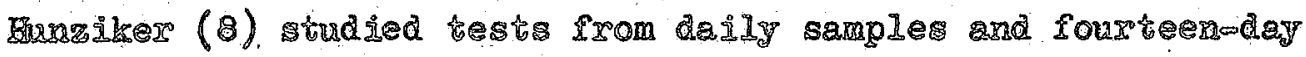
composite samples preserwed with mexcuric chloride. The dajdy samples

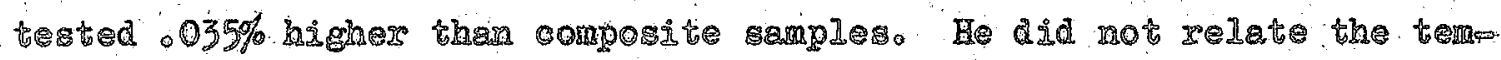
perature of storage or the prosservative used. He also cested periodic samples taken every second, third, fourth axd firth days. It was ob-

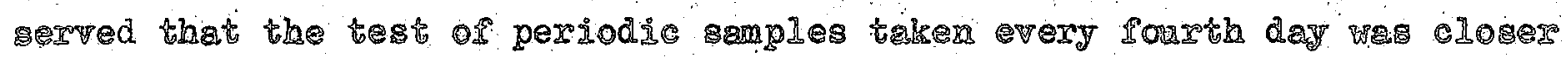
to tho average dajly test thain were the othergo He stated that preserved comporite sanies monld not cover a perod of moxe than seven days. 
Judkin (10) contrasted daily mamles, periodie samples takea twice and three times per morath, and fifteenoday composite samples

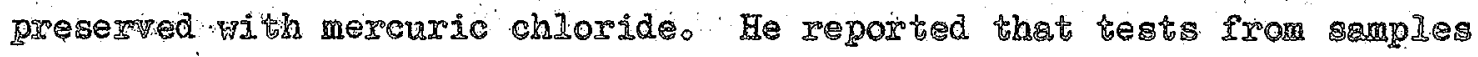
taken three time ger month arerged $0.02 \%$ lower than daily amples while samples takan twice per month averaged s10\% 10wer. The tests srom preserved composite semples averaged $0045 \%$ highers than the dejly sam-

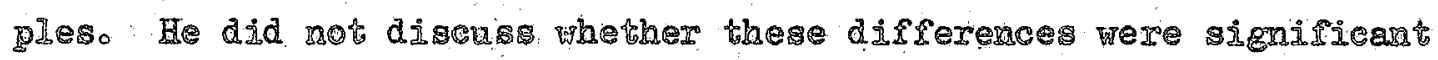
or the temperature at which the composite samples were stored.

LEat (11) observed that thirteanday composite samples stored Wh thercuric chloride at room temperature tested $0035 \%$ lower thes

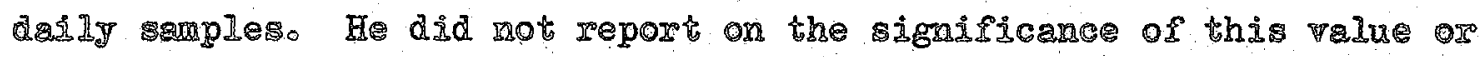
the temperature at which the composite smples were storedo.

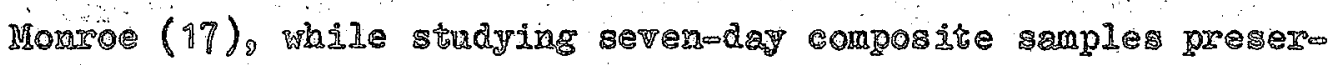
ved with mexcuxic chlorid and daly males, observed that compsite samples tested o0g\% lower than daily samples. He did not state wherher this was of significance or the temperature at which the composite samples were storedo

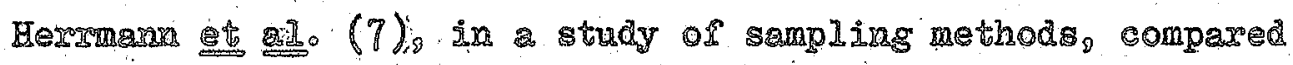
peroiodic semples, smples presexved with mercuric chloride and daíly samples. They found that approminately two out of three single daily samples rall within $2 \%$ of the producers' morthly weighted average buterat percentage the range of variation onaly onemals as great wher four daily maples were averaged. They observed that ten day prew served composite samples stored at $48-50^{\circ}$ Fo tested sigarificanty lower than the daily amples. The teinday composite amples tested $003 \%$ 


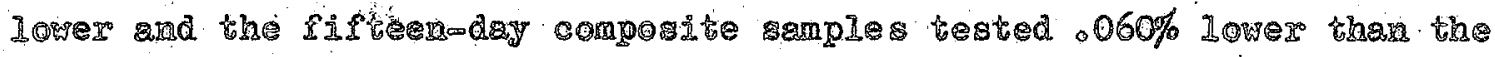
dañ $1 \mathrm{y}$ samples.

Thedman (5) conpared the accuracy of testing periodic, daily and comosite samples He reported that the rat test por $92 \%$ of the geriodic samples taken four times per month did not vary more thash $05 \%$ from the meano The mean talsen from the arerage of the daily testo. In comparing the tests from the composite datily samples he found thot the severn, ter and Ir and $.02 \%$ IOwer, regpectively, than daily saples. He did not report

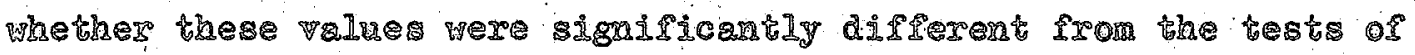
the daily smples. Fe stated that the composite maples were stored whider refrigeration but did not indicate the tompatrure. He did not rellet whether gregervatrite was used。

In reviewing the Iitergture on preservatives, Jekson (9) found that mercuric chIorido was best suited for preserving min gamien. He concluded from his experimental work that o5 gxams would keep a 150 co. amole of min for firten deys at room temperature. He also found tha n excessive mowr of mercuric chloride was not responsible for abrormal testso 
CEAPAER TII

\section{PROCEDURE}

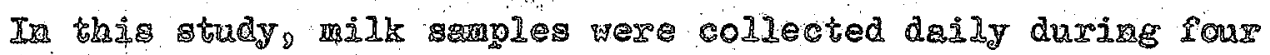

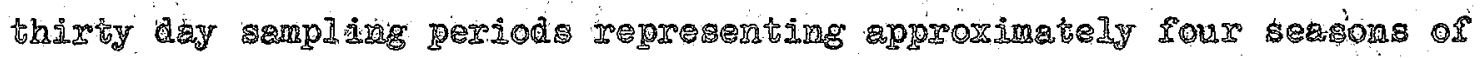

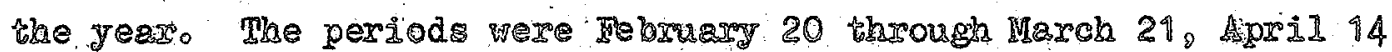

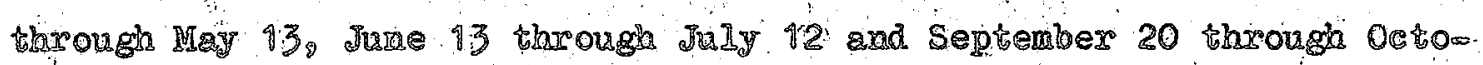

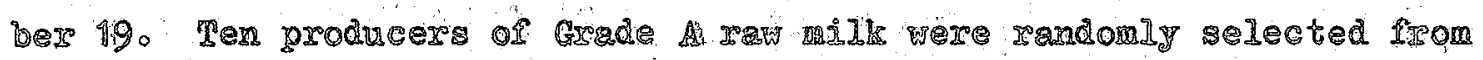

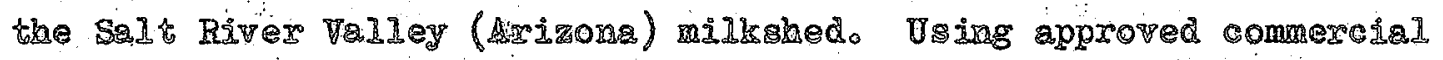
procedrre, the tank truck arivar collected the amoles daily from the Iasm bulk tank of each producero The samples were then placed wader rofrigeration is shaved i a ad shipped via mik trasporse to the milk

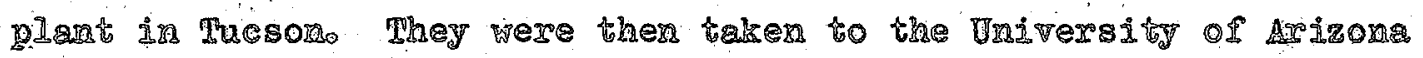
Tore trating in dupleate by the standard Babock method (1) o Hach

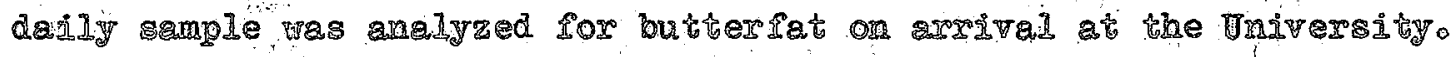
A ine nilititer portios of the daly sample was used to prem. pare erch or the composite mangles mich consisted of two sevenoday

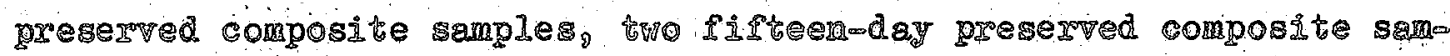

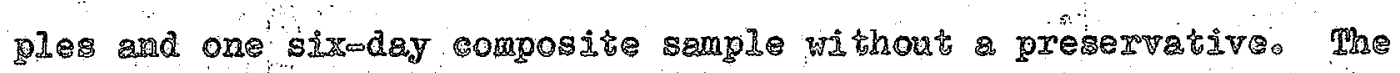

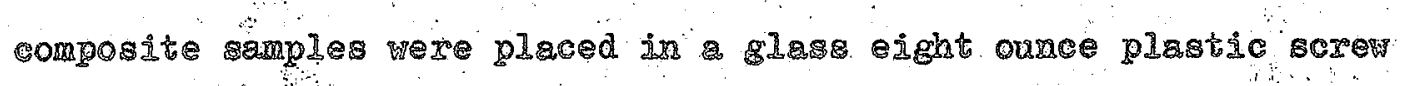
cap containe and kept at $35-38^{\circ}$ s.

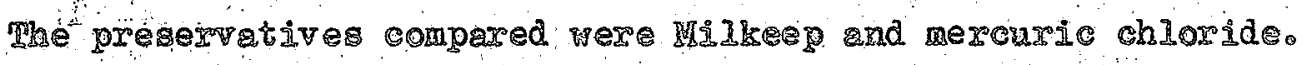

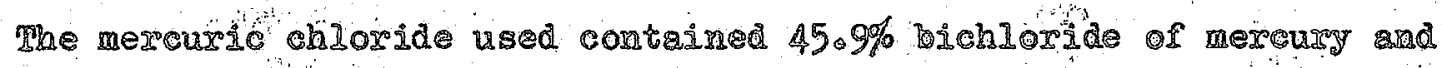


the

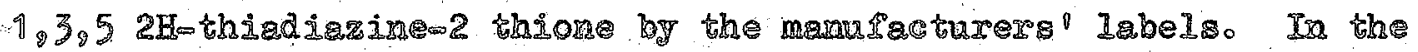
sevenoday preserwed comosite smples, ore tablet of merardic chloride

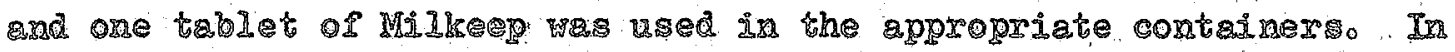
the if

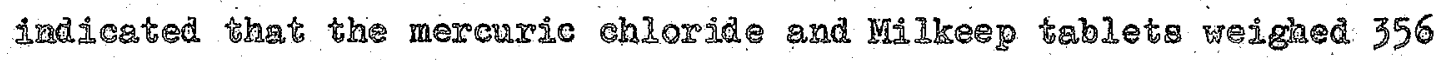
axd 325 milligigem, respectively。

For compardison win the daily and composite testry, periodie

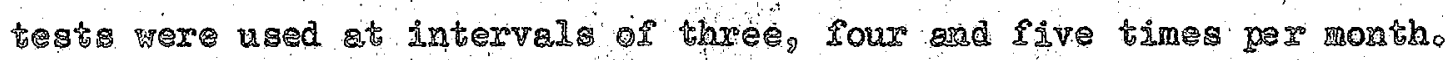

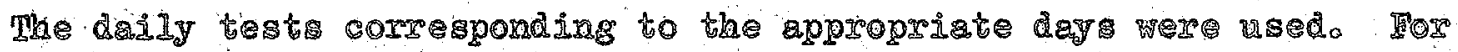

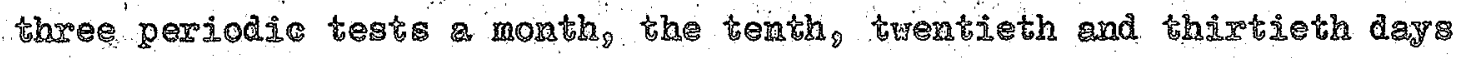
were used In the case of four periodic tests, the days nsed were the

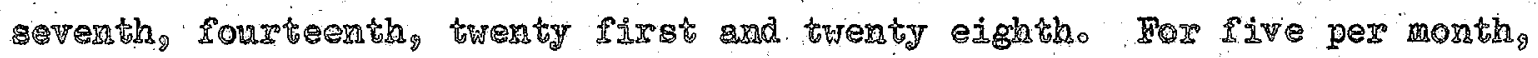

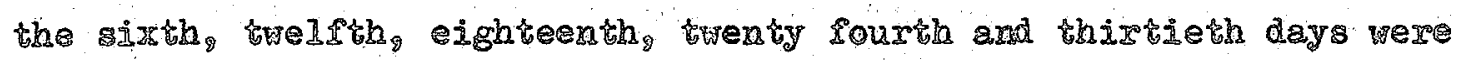
นมีอ

Daily milk meight were taken by the tank truck drityer at the

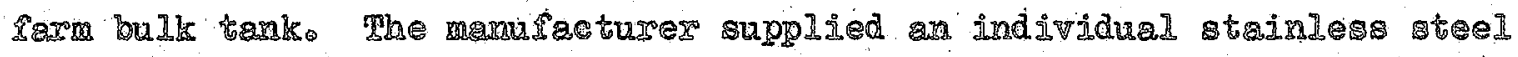
measuring rod and calibration chatit for each tanko 


\section{CHAPRT TV}

\section{DISCUSSIOU OF RESUITS}

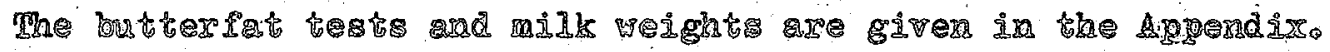

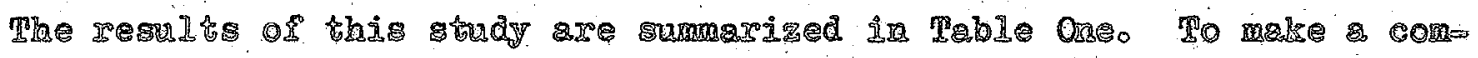

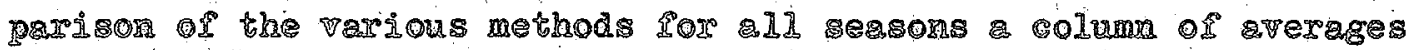

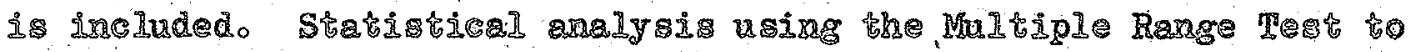
group (5) grif

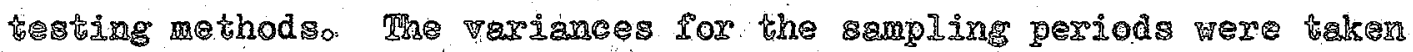

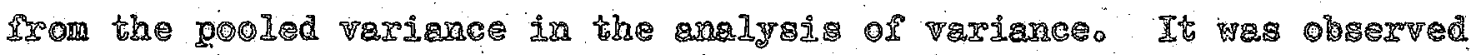
that the vaxiace of the fall gmpling period was greter than the

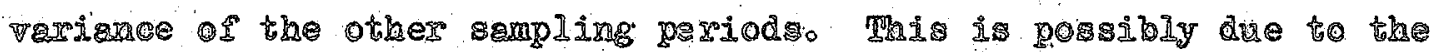

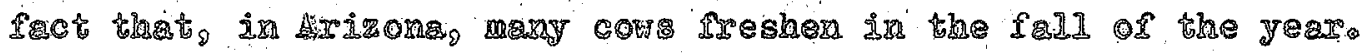

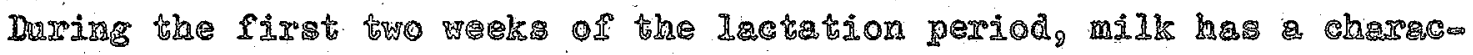

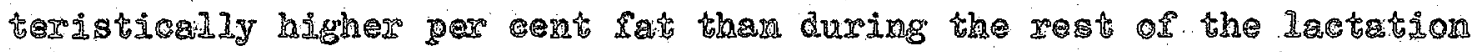
pereiodo

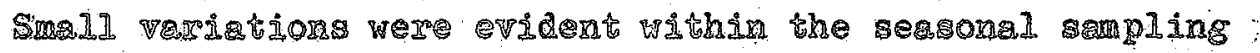

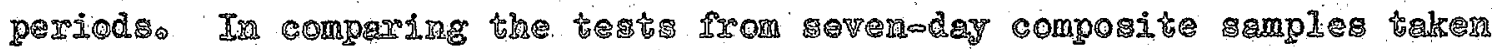

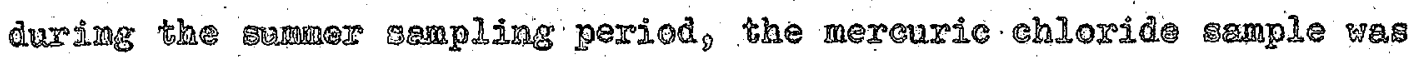
IOu

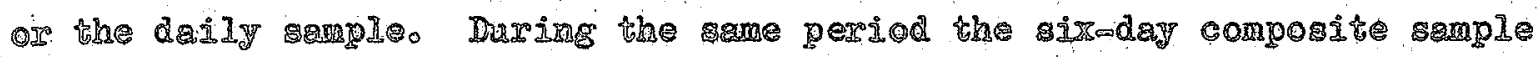

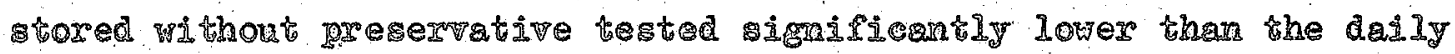


TABLE ONY

ATERAGE PERCENT BUTTERFAT FOR PERIODIC SARPLING, DAILY SAMPLING AITD CONPOS ITE SAMTLING WITH AND WITHOOT PRESERVATIVES

\begin{tabular}{|c|c|c|c|c|c|}
\hline \multirow{3}{*}{ Type of Sruple } & \multicolumn{4}{|c|}{ Sampling Perogo } & \multirow{2}{*}{ Averags } \\
\hline & Iad1 & Viatese & Spring & Suromes & \\
\hline & $(\%)$ & $(\%)$ & $(\%)$ & $(\%)$ & (\%) \\
\hline $\begin{array}{l}\text { SevernoDay Preaerved } \\
\text { Compositse }\left(\mathrm{Hg}_{2}\right)\end{array}$ & 3.72 & 3.64 & 3060 & 3.79 & 3.69 \\
\hline $\begin{array}{l}\text { SeVen-Day Pregryed } \\
\text { Composite (HIIkeeg) }\end{array}$ & 3.75 & 3.63 & 3.62 & 3088 & 3.71 \\
\hline DEd 197 & 3074 & 3063. & 3.63 & 3.85 & 3.71 \\
\hline $\begin{array}{l}\text { Pistorand Preserved } \\
\text { Composit: }\left(\mathrm{HgCl}_{2}\right)\end{array}$ & 3.70 & 3.62 & 3.59 & 30.82 & 3.68 \\
\hline 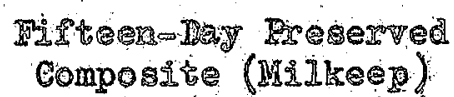 & 3.74 & 3.61 & 3.60 & 3.85 & 3070 \\
\hline 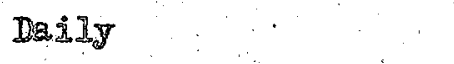 & 3.75 & 3.63 & 3.63 & 3.85 & 3.72 \\
\hline $\begin{array}{l}\text { SirzoDay Composite } \\
\text { (Hot Eceserved) }\end{array}$ & 3.74 & 3.65 & 3066 & 3.81 & 3072 \\
\hline Do:21 & 3.75 & 3.63 & 3.63 & 3.85 & 3.72 \\
\hline $\begin{array}{l}\text { Teriodie Taker } \\
3 \text { Time Per Month }\end{array}$ & 3082 & 30.65 & 3.63 & 3084 & 3074 \\
\hline 4. Times Ber Morth & 3.80 & 3.64 & 30691 & 3091 & 3074 \\
\hline 5. Pimes Ler Hoth & 3.78 & 30.62 & 3.64 & 3.85 & 3.72 \\
\hline Daidy & 3.75 & 3.63 & 3.63 & 3.85 & 3.72 \\
\hline $\begin{array}{l}\text { Amerage of Roolled } \\
\text { Verrigaces }\end{array}$ & .0410 & .01035 & .01279 & .00920 & $\infty$ \\
\hline
\end{tabular}




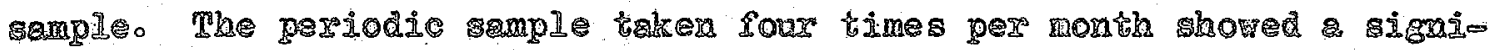
fficanly higher tert then the periodic mple token either tharee or

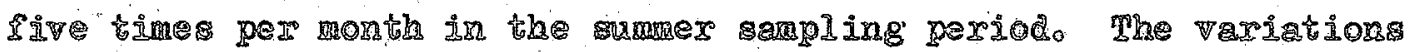

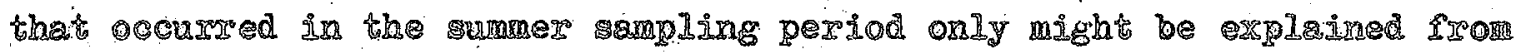

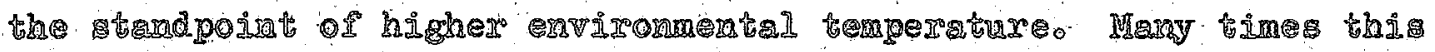
tomprature wes $90^{\circ}$ Fo higher. There were indication that during

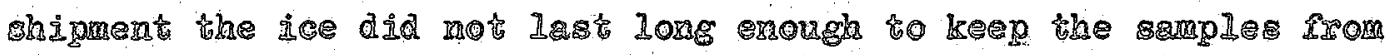

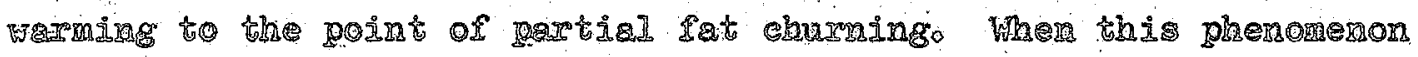
oecuxred paticies of chrmed fat olvag to the sides of the ample both le. kren by using recommended procodures of semple greparation it

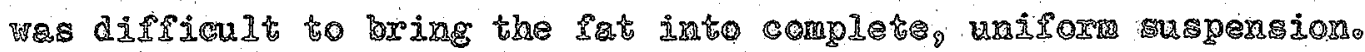

Brom the results it appens tha most economical method would be by periodic amplang ard testing three times per montho since acuragy as well as cconony of testing is a ractor, both the periodic samples taker five times per mon and tro

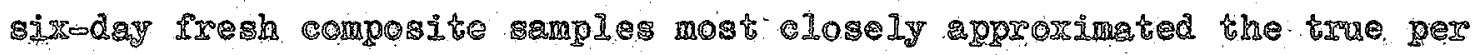

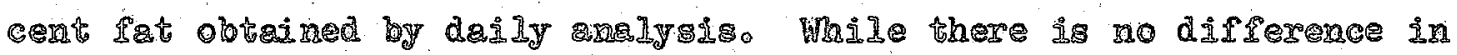

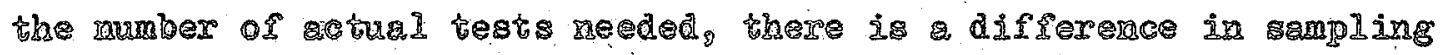

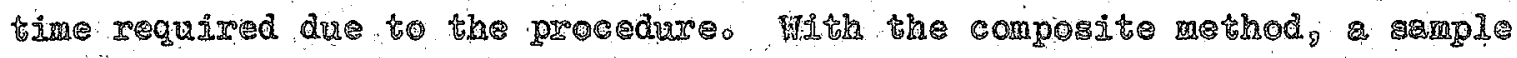
mat be collected and placed into a container, agingted ard refrigarated ach day for a poriod of siz days and then tested. This involves a certain amown of labor in toking nat hading the samples. The sive time nem poriodic method reguitres smpling and testing every sixth day orly。 A comperison of the sixoday composite mamples and the

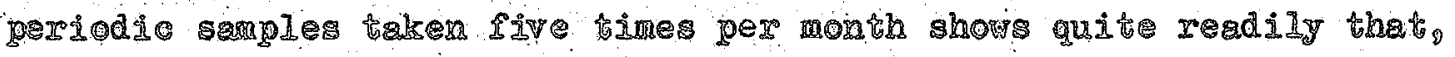




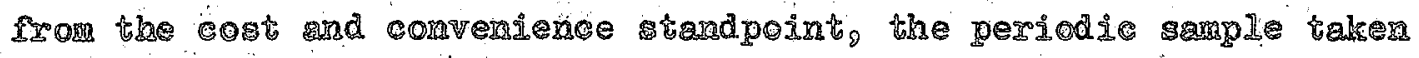
rive times per month would be more farorable.

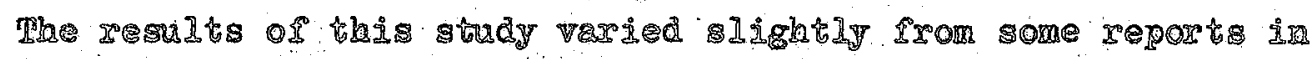

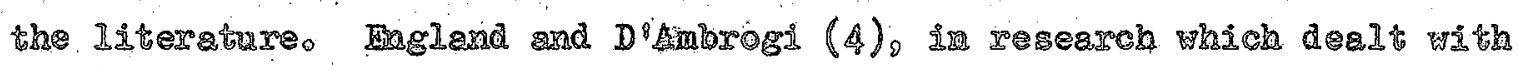
- Iarge amaber of variables including storage temperatues of 45,60,

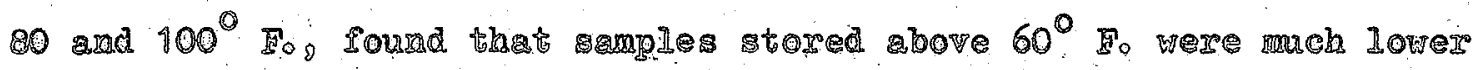

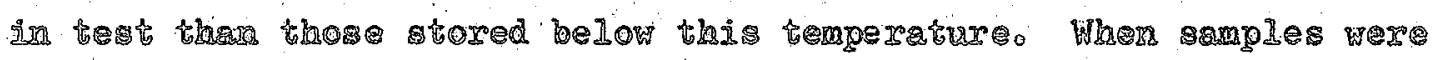
stored at $45^{\circ}$ Fo the dajy samples arexged $064 \%$ migher than preserved

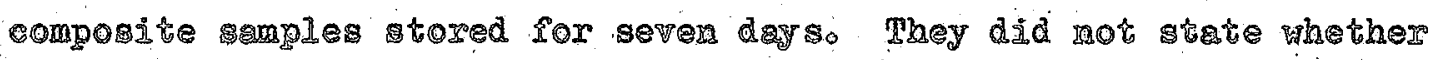

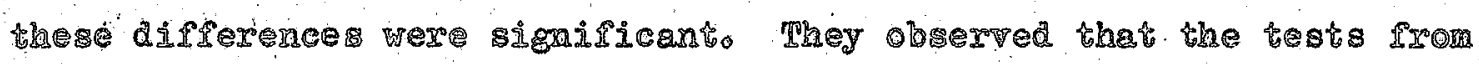

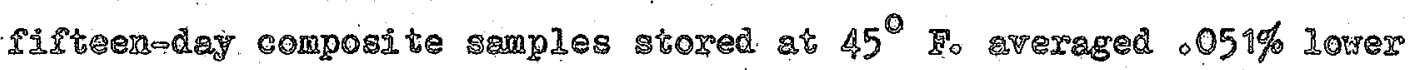

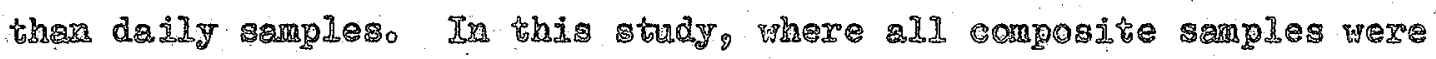

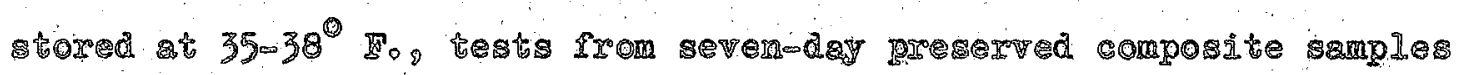

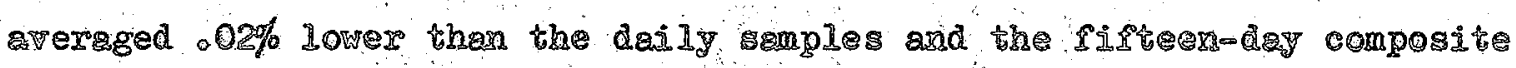

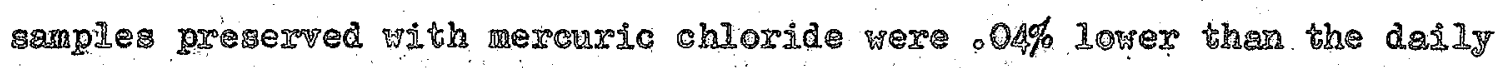

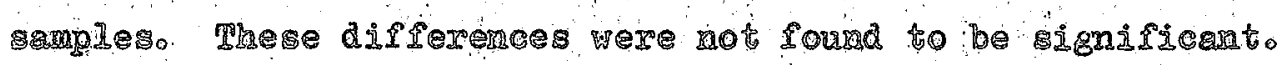

Treas (13) sound that tests from preserved composite smples

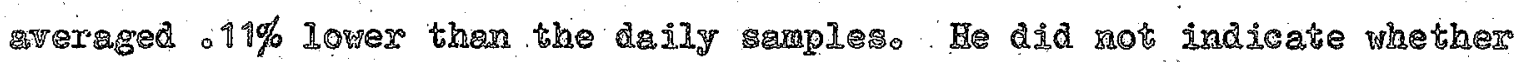
hน ature st which the samples were stored。 Monroe $(17)$, while atudying 30renoday composite serples preserwed with mercuric chloride ard

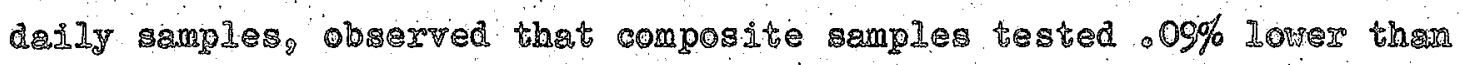

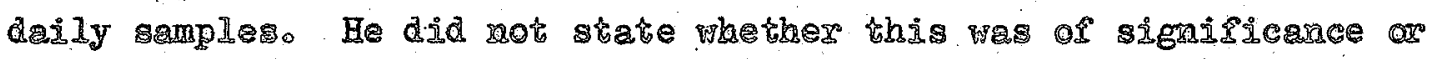
the temperature at which the compost te sam wes were stored. In a com

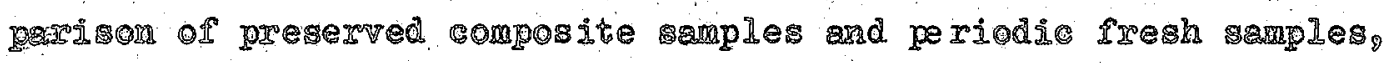




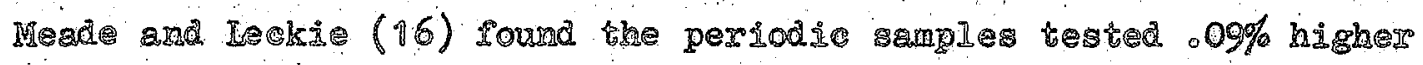

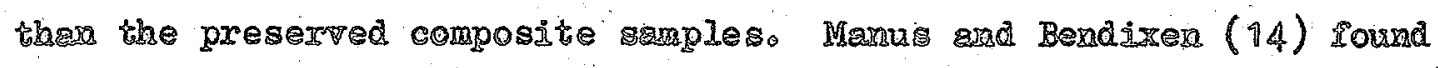

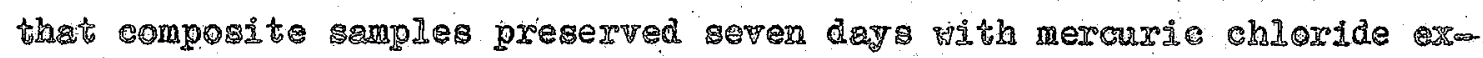

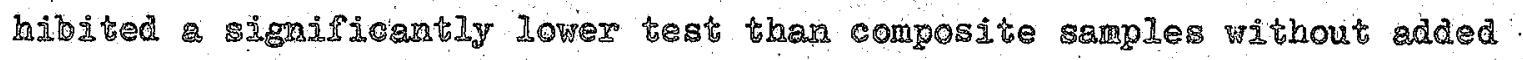

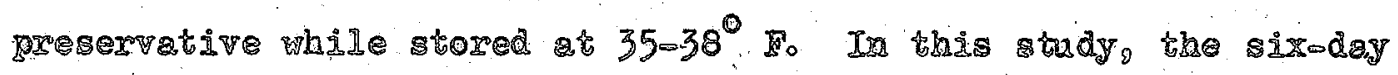
composice sampleg mithout preservative tested $003 \%$ higher tran the

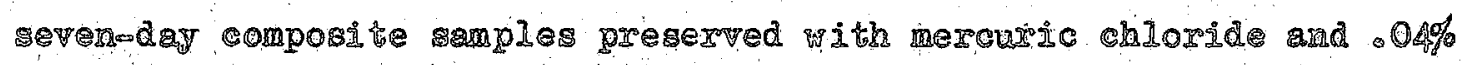

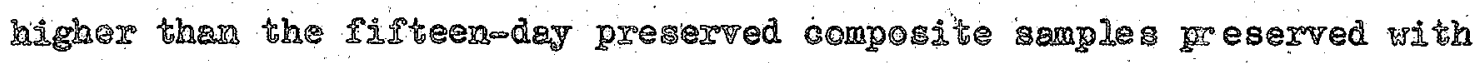

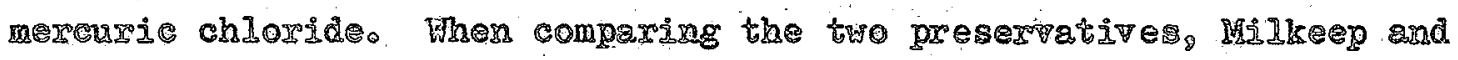

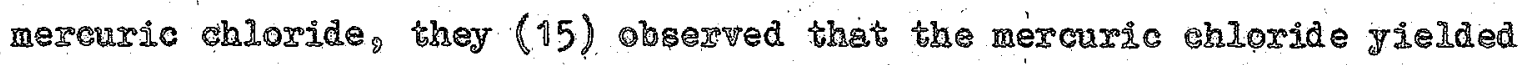

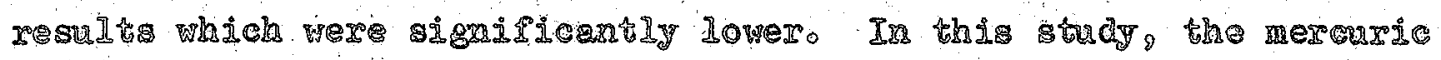

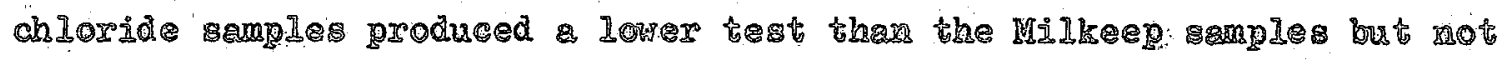
low enough to be of signifiearse.

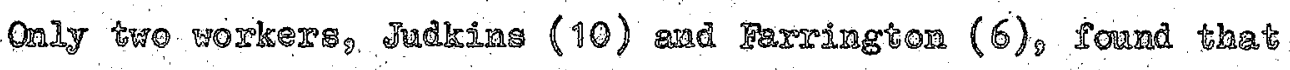

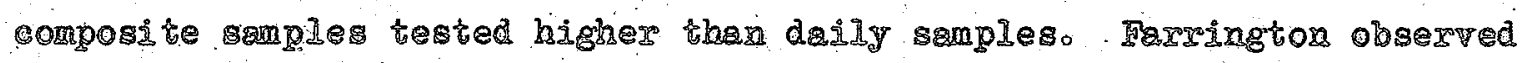

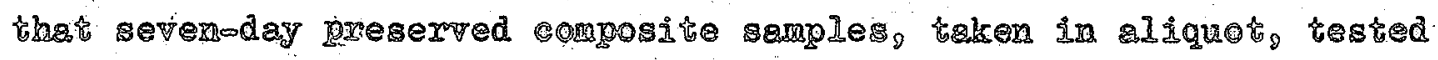
-02\% righer than the daily sampledo Tho preserved composite samples

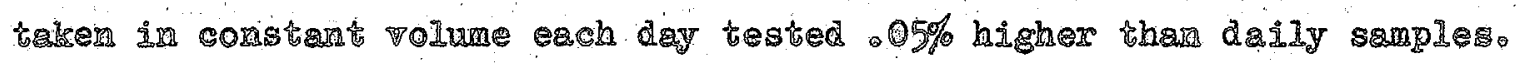
The comporte sanples without preservatives tested od\% higher that

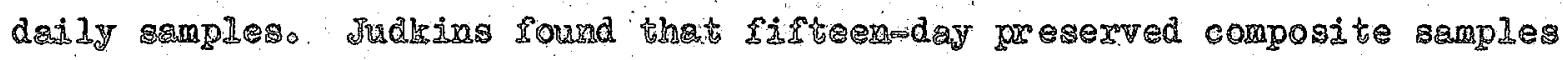
tested $045 \%$ higher ham daid samples. In thig study sovenoday com posite amples preserved whis mercurio chloride tested or\% lower bara

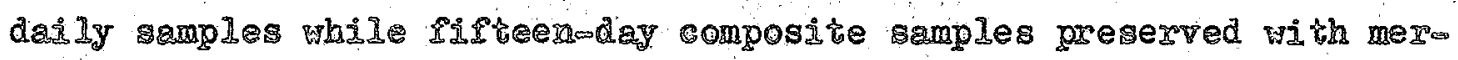

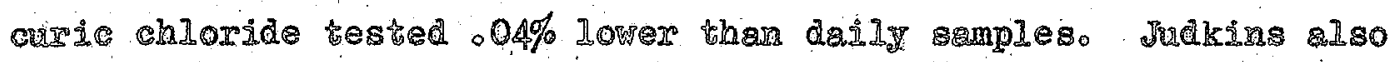
found thet periodic sanples taren three trues per month areraged o0\% 


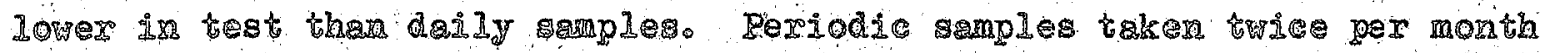
tested .10\% lowex tha dajy samples geriodic samples trken twice per worth were not wsed in this study however tests from periodic samples

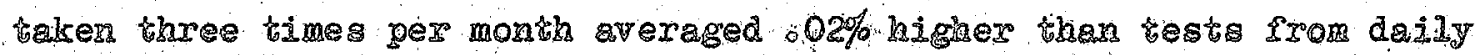

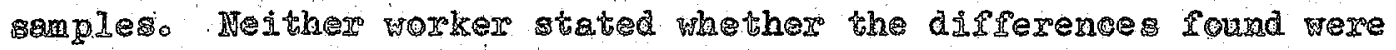
gignisican or the temperature at which the composite samples were storedo

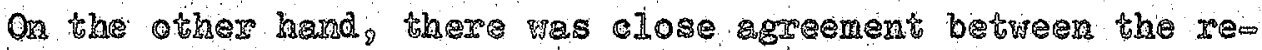
anlts of this stroy and some other reports in the literature. Tuckey (19) obserwed a diference between daily samples and preseryed composite amples sored for sever day at $40^{\circ}$ Fo Ia all cases they: 'Sound daily sampleg testing from .02\% to .064\% bigher than the preo served composite samples. Dhey did not state whether these ralues were gxeat enough to be of significance. In study by WIIster and Houlohan (20) comparing fresh daily samples and preserwed conposte amples. stoxed for five, seven and fifteen days at $35-38^{\circ}$ so they found comporite amples tested lower than da기 samples. The fiveaday compost samples tested $0016 \%$ 10wer the sevenday o021\% Iower and tho the riteenday .027\% lower thar the daily samples, but the dirference mere not large enough to be aigairjeanto In this study sevenday como

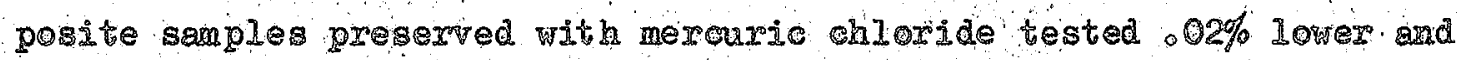

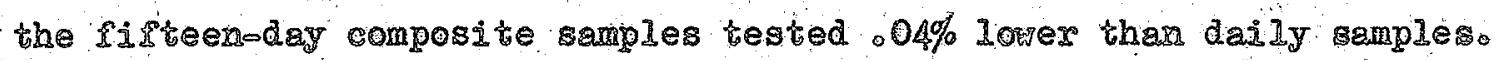
In two trials comparing dajlý samples with firteenoday preserved com

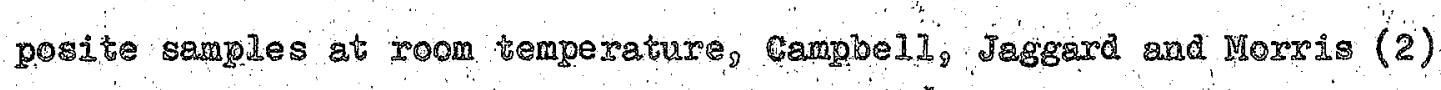
found that ifiteenclay greserved composite samples tested o02\% lower 
than daily smples. They did not report on the statistical significance of the differences found.

Ineas (13) reported in a comparison of periodic samples taken fong and elght times per month and daily samles that the difference was not arficient to be significant In the same type of comparisong Saxaran and Oferman (18) Sound that periodic samples colleched sive tines per month moxe closely aproximated the frue butserfat parcentage thata these taken four times per wonth as wa tso the in this stradyo

In compring daily tests and four teenoday preserved composite tesis Hamikex (8) fownd that the dacily samples tested .035\% higher thas the composite samples He did not indicate the temperature of storage or wether the difference cited was significanto In testing periodic smples taken every second, third, fourth and fifth day, he found samples tested every fourth day averaged closer to the daily te

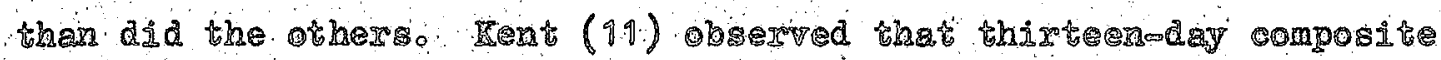

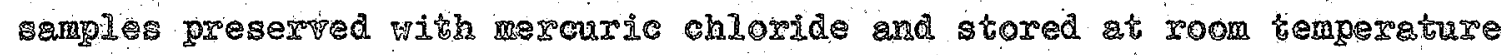

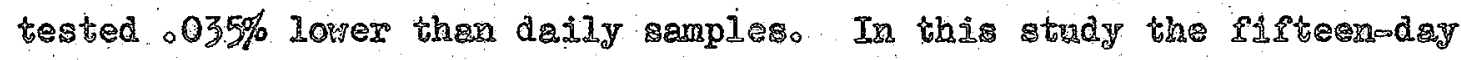
composite samples preserved wh meremic chloride tested .04\% Lower

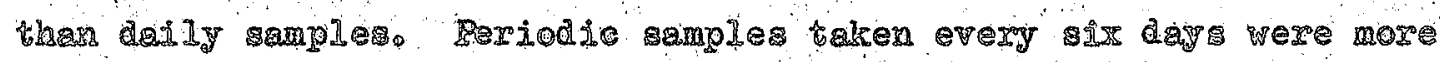
accurate than periodic samples token every ight and ten days

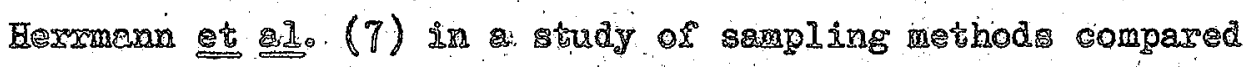
periodie, prewerved comporte and daily samples. they found that pgproximaly two out of three single daly samples fell within of of the groducers" month veighted average butterrat percentagen. The 
raxge of waxiation was only onewalf as great when four dajy samples were averaged. They obsexwad that tenoday masered composite samples tested significanty lower that the daily samples. The texoday compo site samples tested $039 \%$ lowex and the firteenday sangles tested $0060 \%$ lower ther daily smeles. The composite mamples were stored at

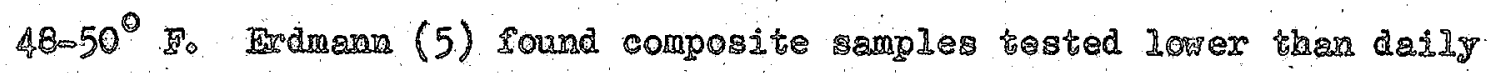
samples. Seven-day composite amples were $00 \%$. 10wer, the ternoday composite samples were 。0\% lower than daily samples. He did not reo port whother these values were sigmificanto He stated that the compo site samples wex yefrigexated but did not report the temperature In this study, tenoday composite samples were not used, but sevenoday ad fifo $.02 \%$ and $0.04 \%$ lower, respectively, than dajly amples.

In eaxly work, Cooke and Hils (3) compared periodic samples taken every fourh and exgh day with daily saxples。 They reported that there was Iess waxiability in sampling every fourth day as opposed to sampling very eighth dago Results of this study also have shown that the more rrequent gampling gives greater accuracy. 


\section{GEAPRER $\nabla$}

\section{CONCIUSTONS}

Ir this study Sat tosts we compared using daily sampleg: siroday composite samples without pterexvativo seren and lifteen-day presered composite samples and pexode saples taken three, foux ara fire trmes per moxtho The remlts show that

1. There was greater vartability in the sumer sampling period thas during orher samping pexpods. In the sumex sampling period the average test of the serencday compoito samples preserved with mercuric chloxide was jgnifoanty lower than ejthex the sevenoday comogite

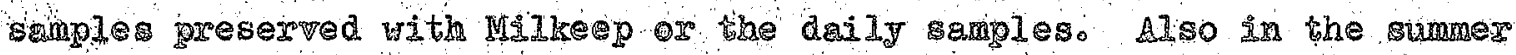
rampling period the average of the siz-day composito samples whthout Tresexvatre tested agniffeanty lower than the dajly sanples. The

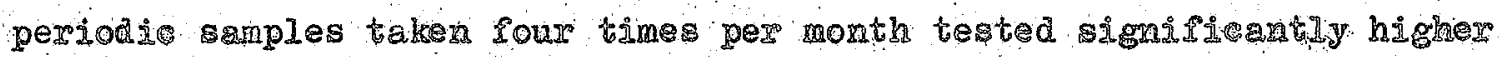

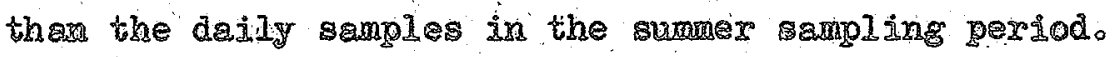

2. Whexe mere 20 signi in the sal wines or spring periodo

3. The laxger tariance found in the fall saning perjod is

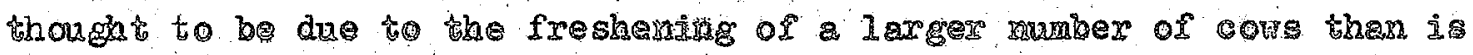

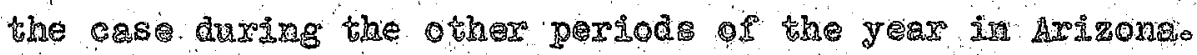

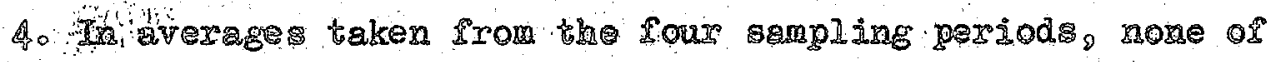
the difrerenges were large enough to be significanto 
5. The tests fron daily samples were consistenty bigher thas the terts from both the seven and the fifterom day preserved composite somoles im 2.11 semplimg periods.

6. Seven and fiten-day composite samples preserved with Nilteop consisteatly tested higher than seren and rithonoday composit ganples preserod with mercurie chloride.

7. Average rest: from six-day comosite amples without adad

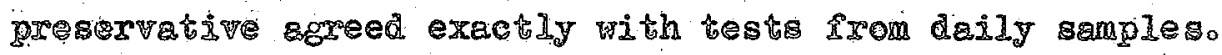

8. Pariodic samplos taken both three and four thes per month

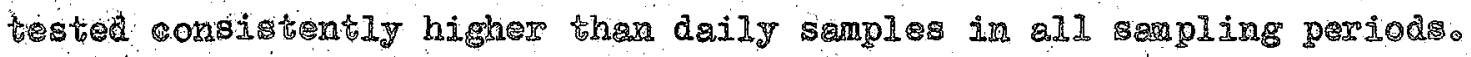
9. The average tost from the periodic samples taken fire times per month wex identical to the average test of the daily amples. 


\section{ITEGRATURE CITED}

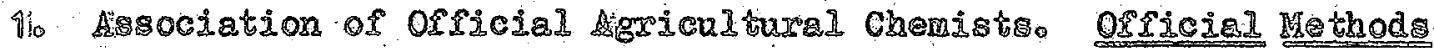

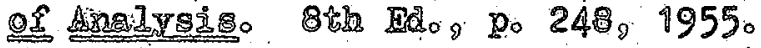

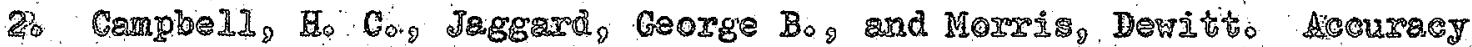
of the Composte Testo The Milk Deal ex $21 \% 42,1931 \%$

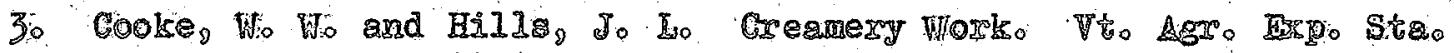
Atano Repto: 1891 .

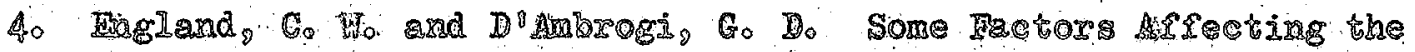

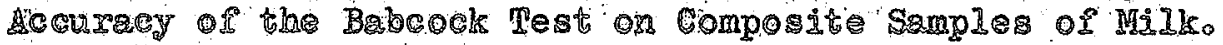

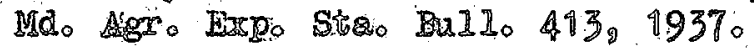

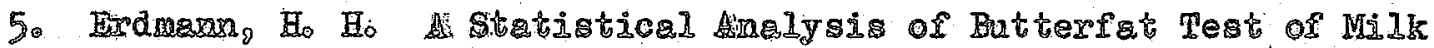
Based ar Rardom Freak Milk Sempingo Fed. Mj Mk Maketing

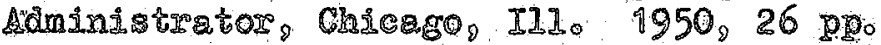

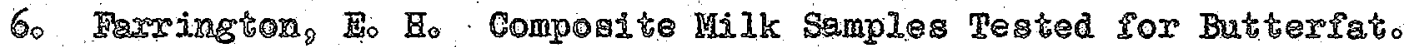

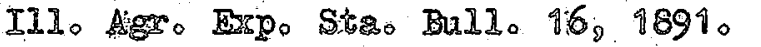

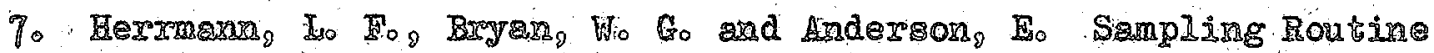

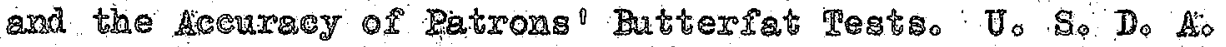

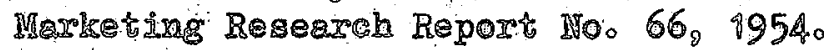

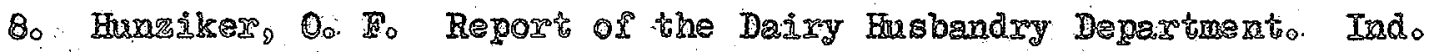

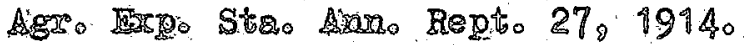

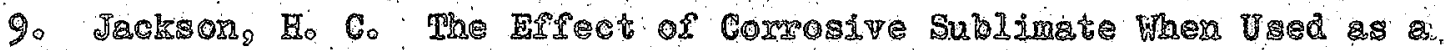
Preservative in Composite Sapleso. Jo Dary SGio $2: 170,19190$

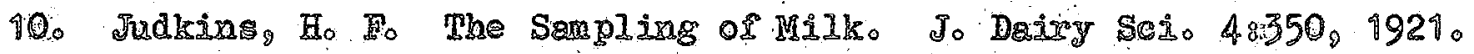

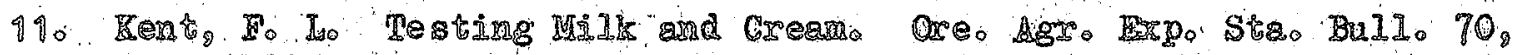
19020

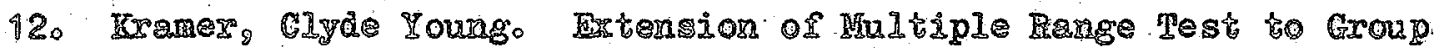
Merns with Urequal Hubero of Replicationso So Biornetric Socsety $128: 307,1956$

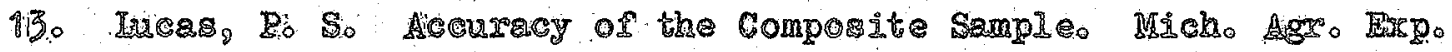
St8. Ba 10 158,1938 。 


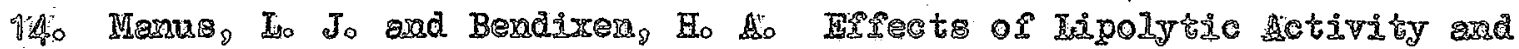

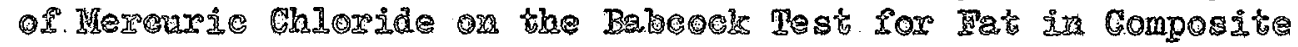

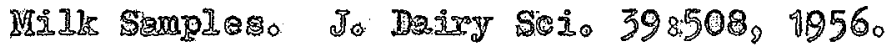

15. Manus, Io jo Berdixen, Ho

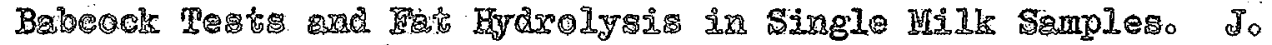

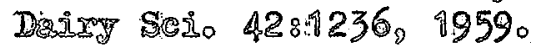

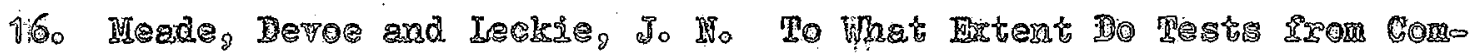

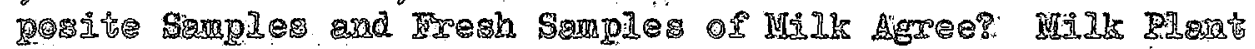

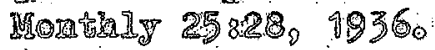

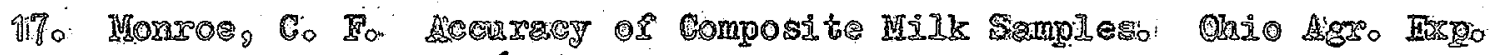

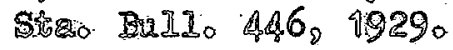

Ti8

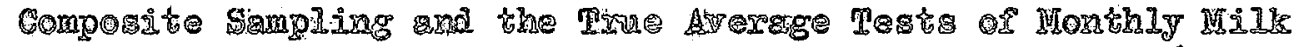

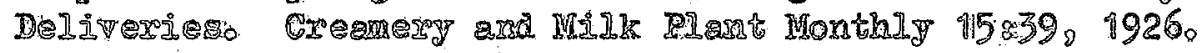

19. Trear, $\mathrm{K}$ -

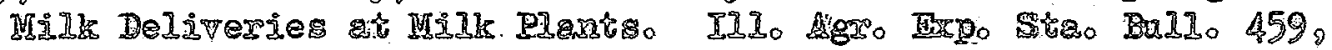
1939.

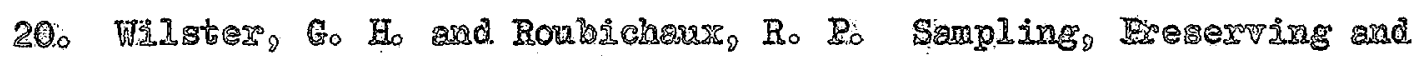

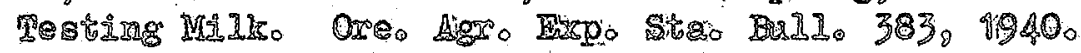


APPEIDIX: 
BUTTRR FAT ANALYSIS FCR FALL SAMPLING PERIOD (September 20 through october 99 )

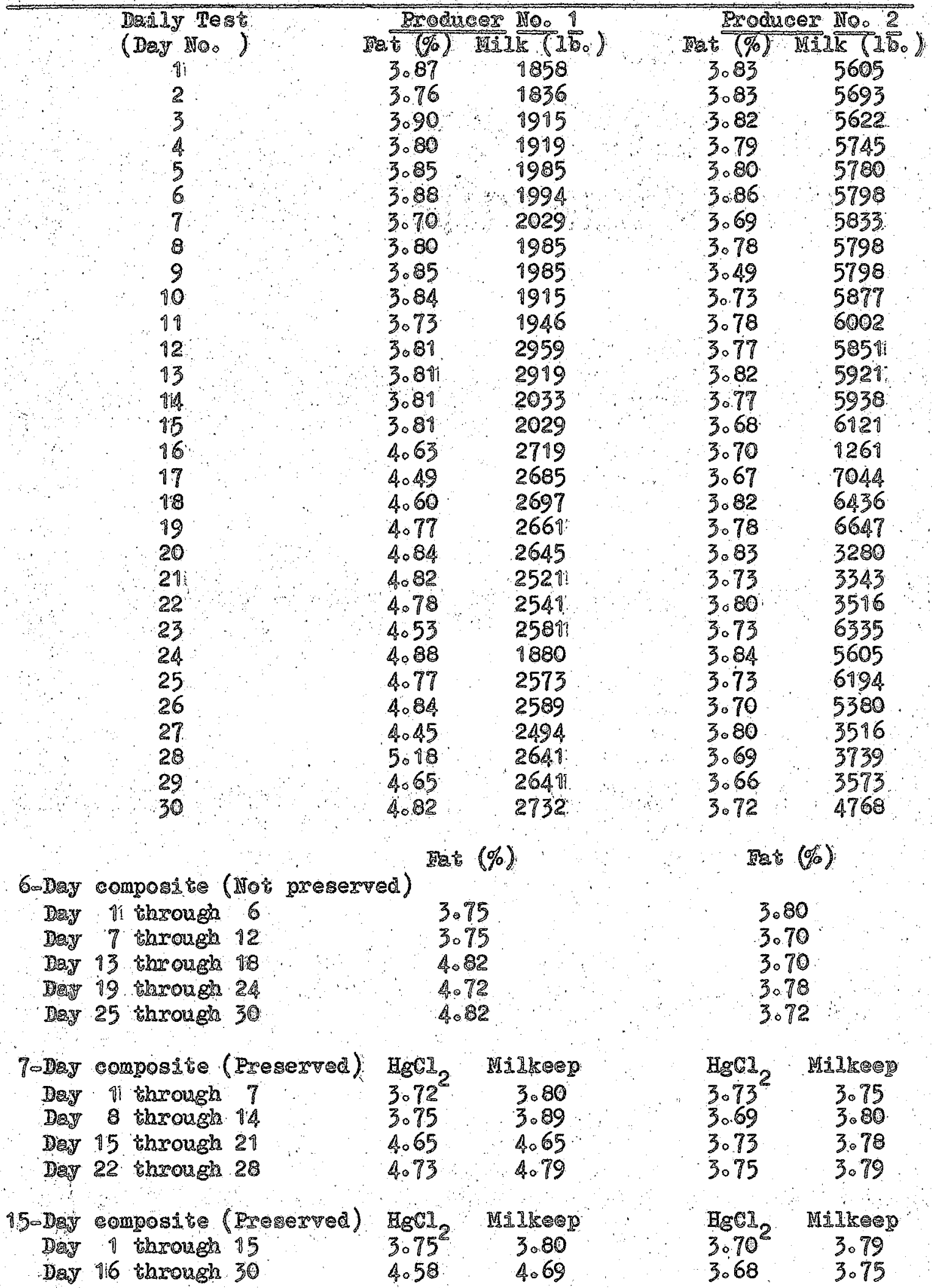


FOTOQ

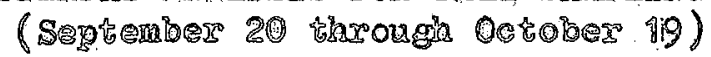

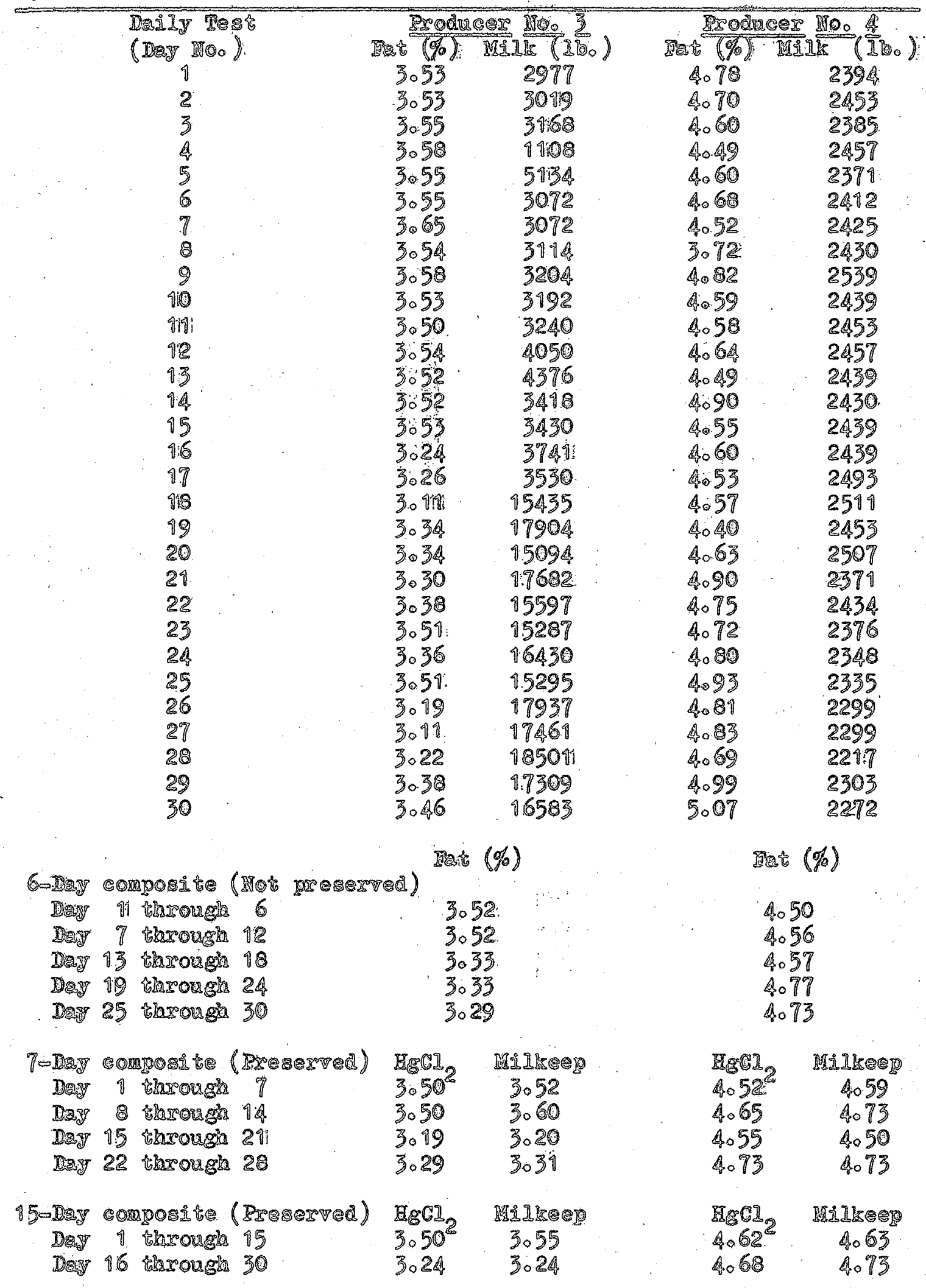




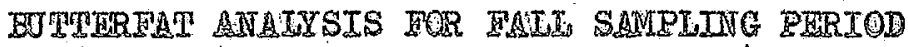

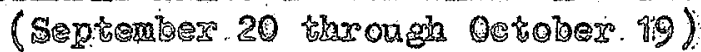

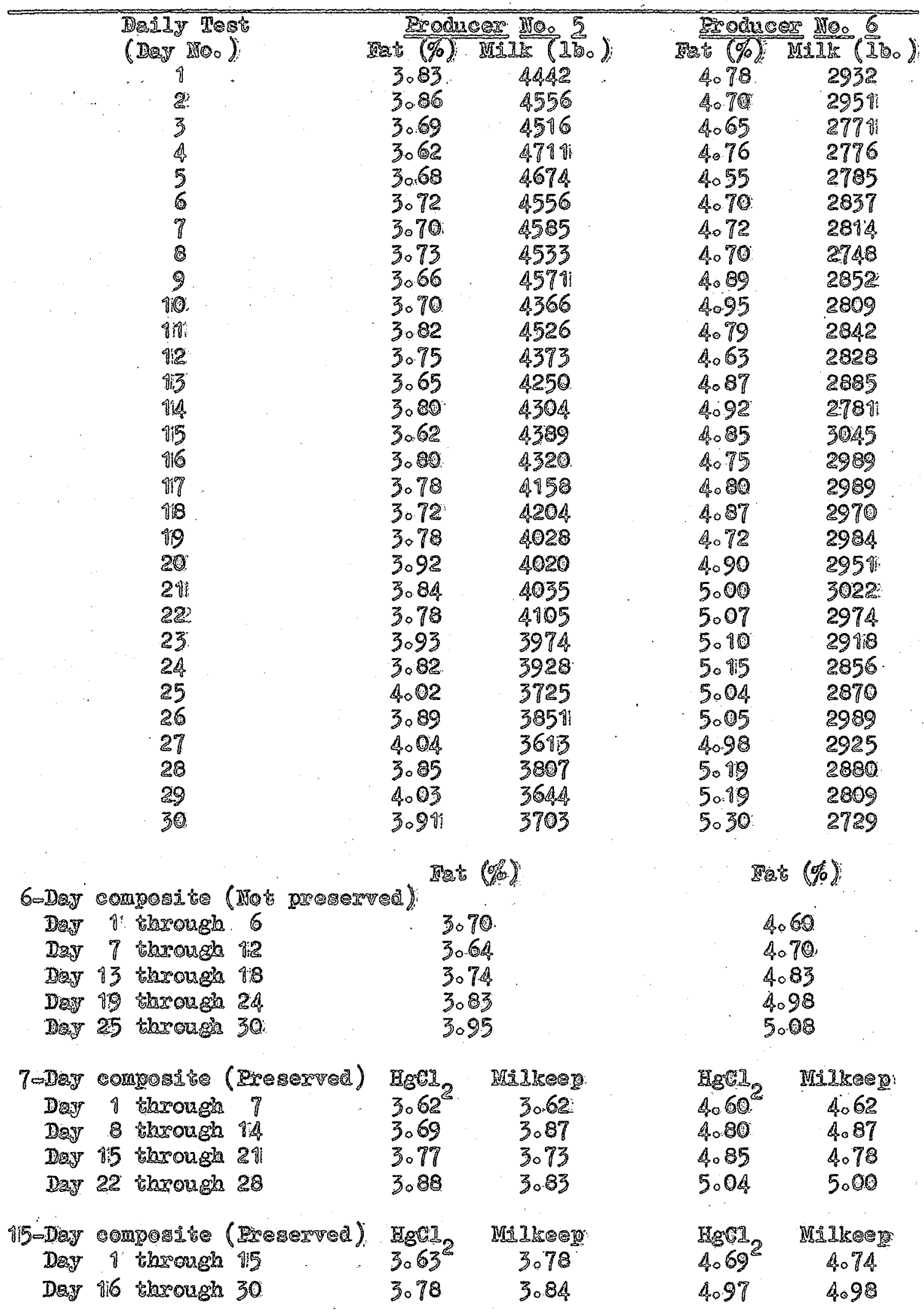




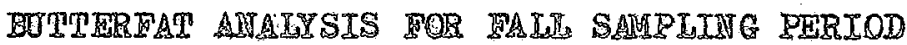

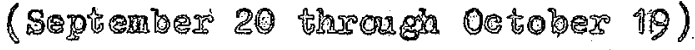

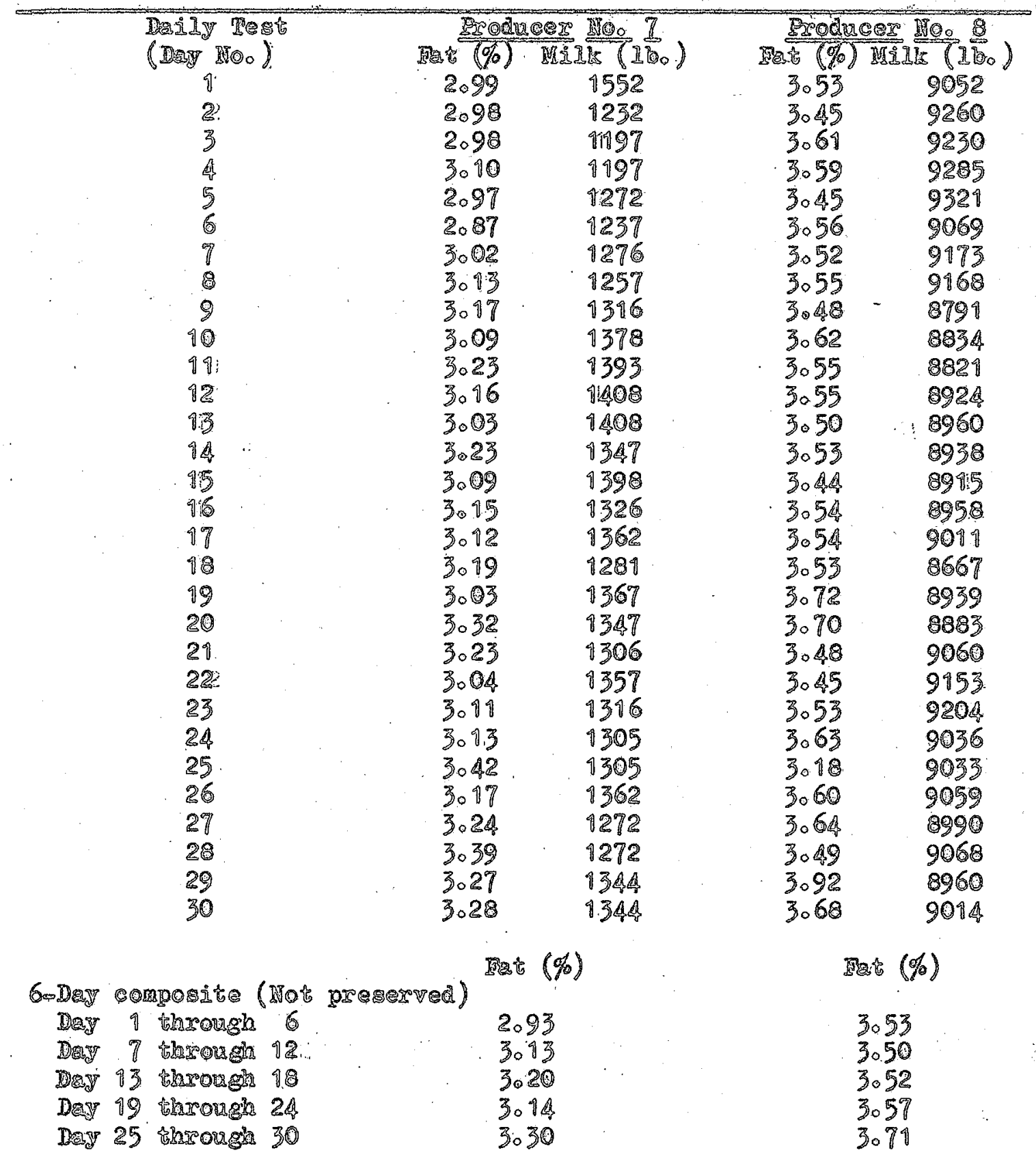

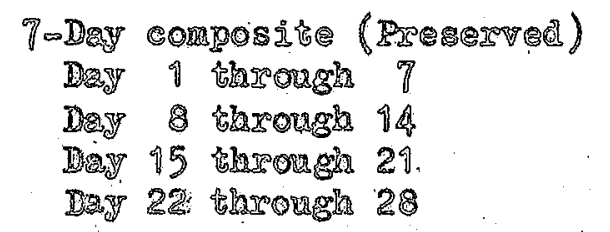

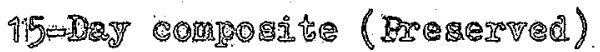

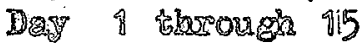

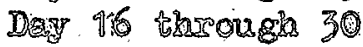

\begin{tabular}{|c|c|}
\hline $\begin{array}{l}\text { Bged } \\
3.00 \\
3.13 \\
3.18 \\
30.23\end{array}$ & 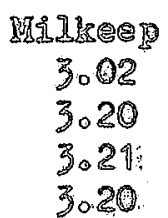 \\
\hline
\end{tabular}

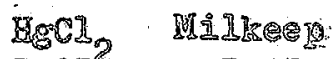
$3005^{2} \quad 3015$

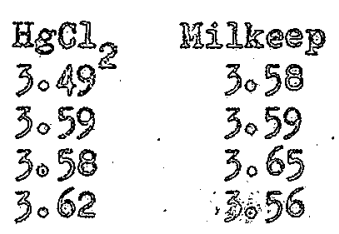

EgG $3049^{2} \quad 3.56$ 


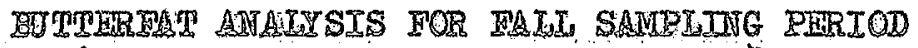

(September. 20 through Qetober. 19)

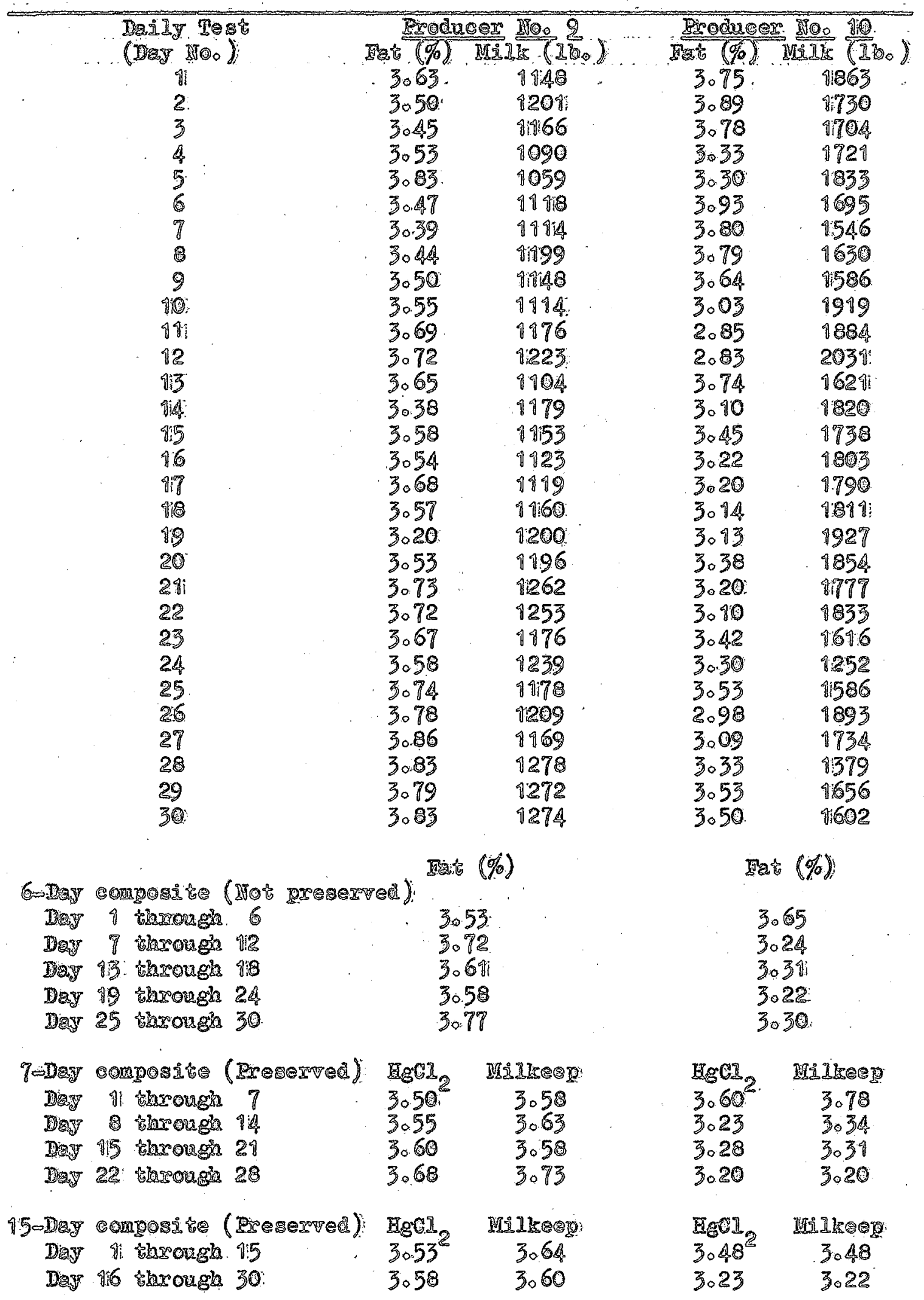


BJTYSHRAT ANALYSIS FOR WINTER SAIAPLING PBRIOD

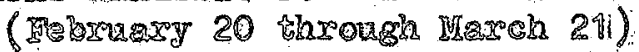

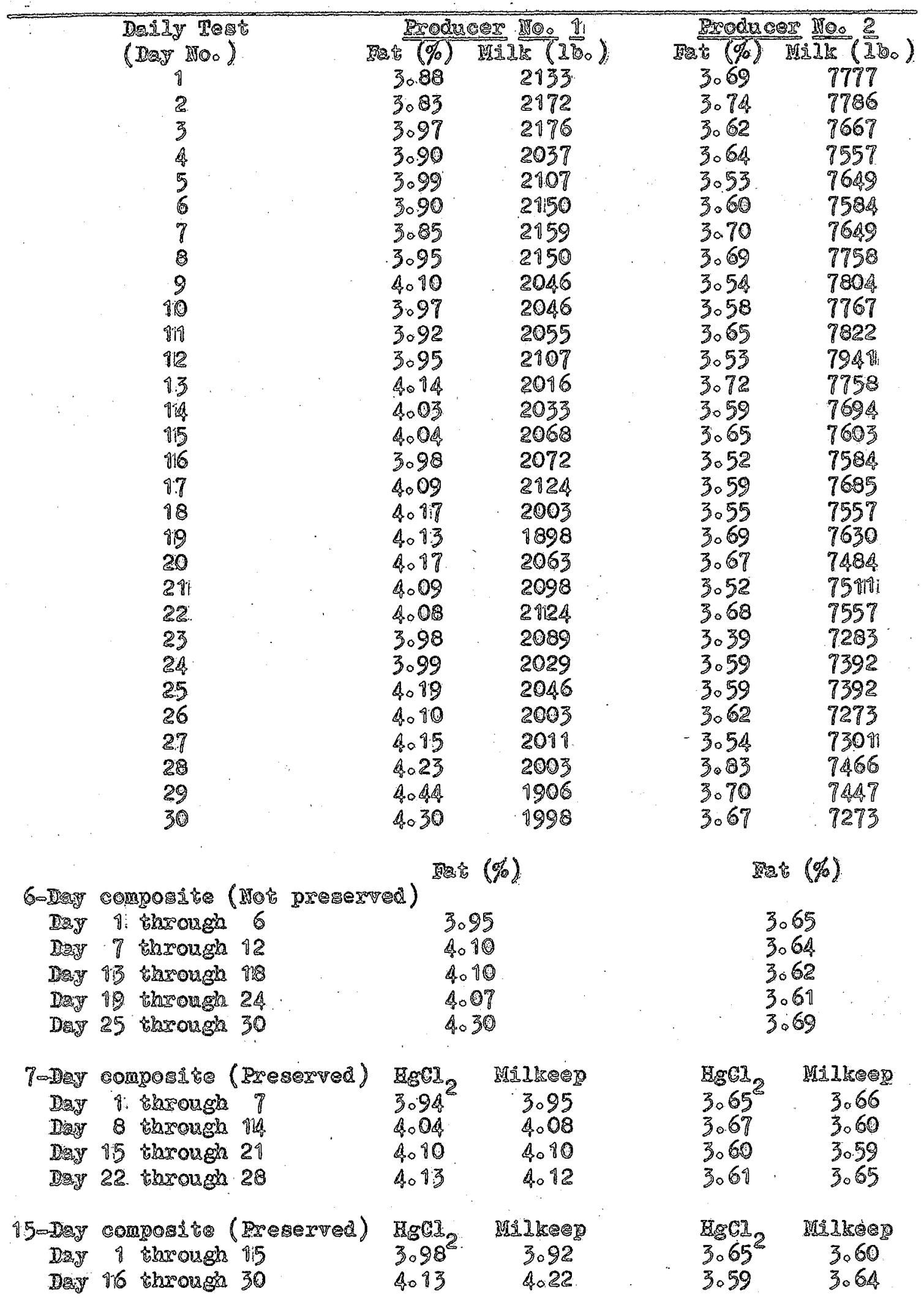




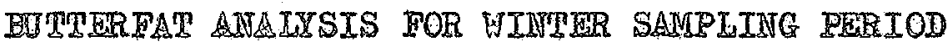

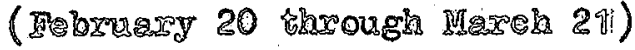

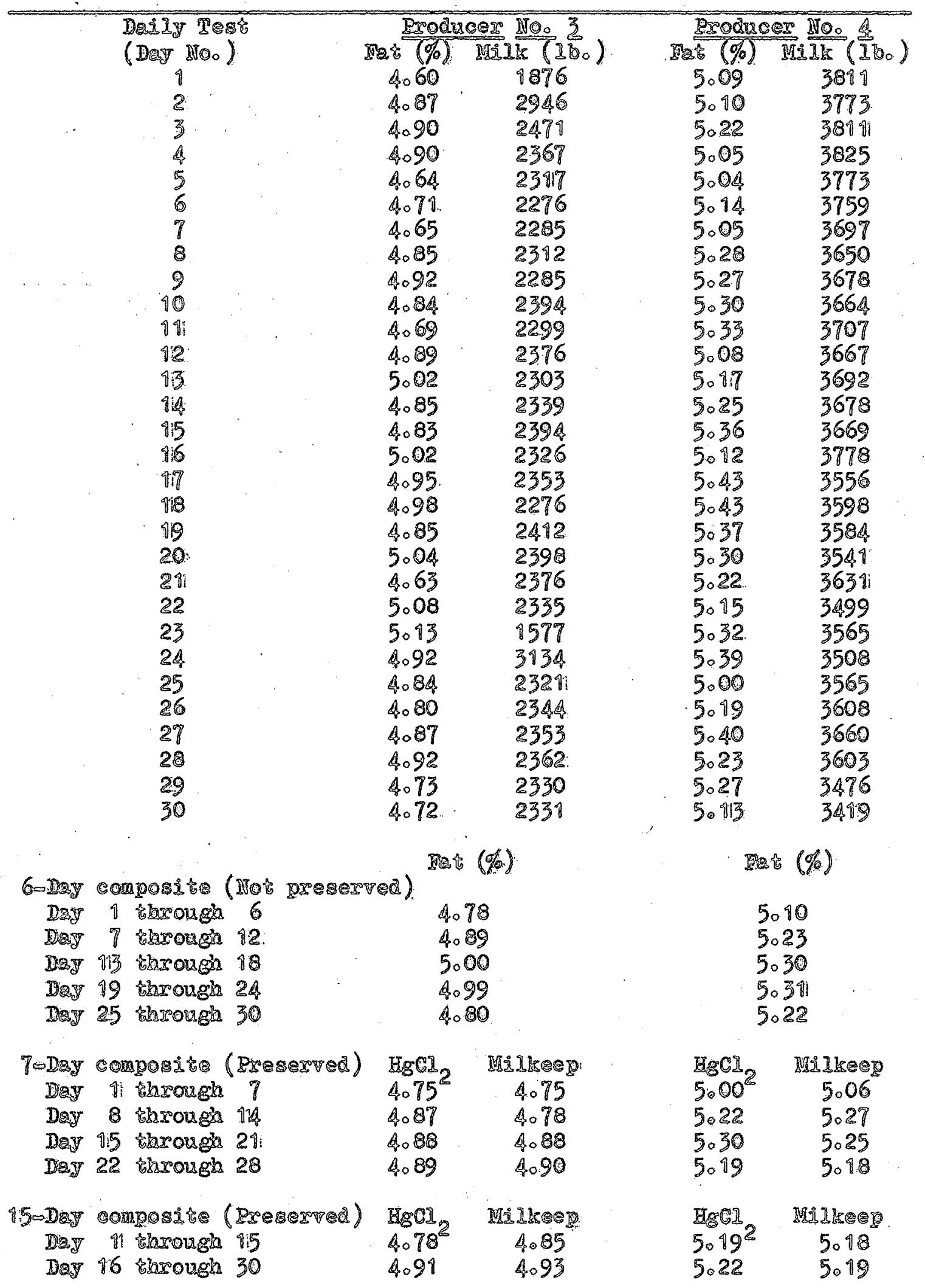


ZUTPERFAT ANALISIS FOR WTITER SAMPLING PERIOB (February 20 through Naroh 21)

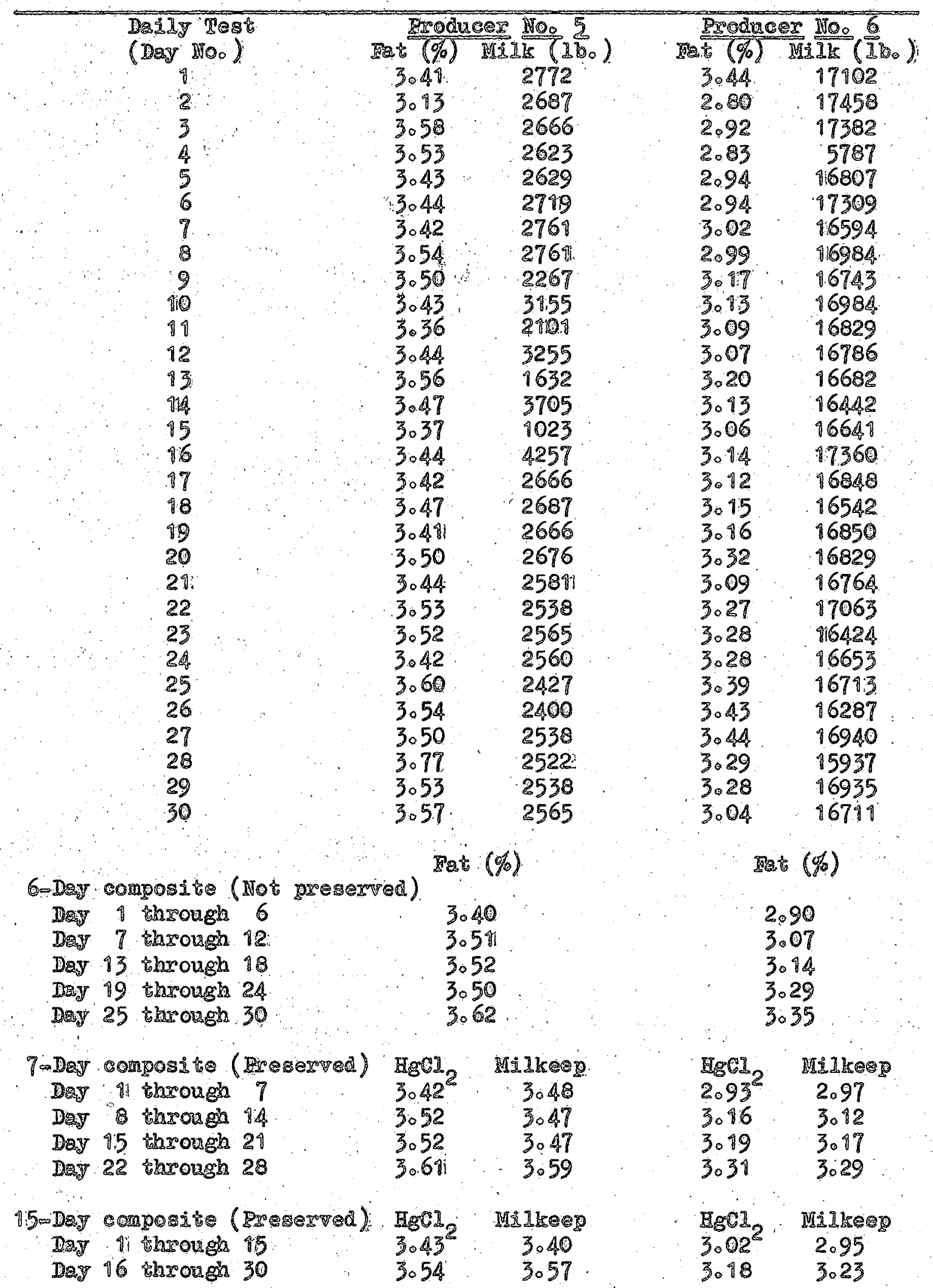


BUTRERTAT ANALYSIS FOR WINTER SAMPIING PERIOD

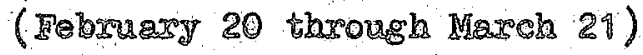

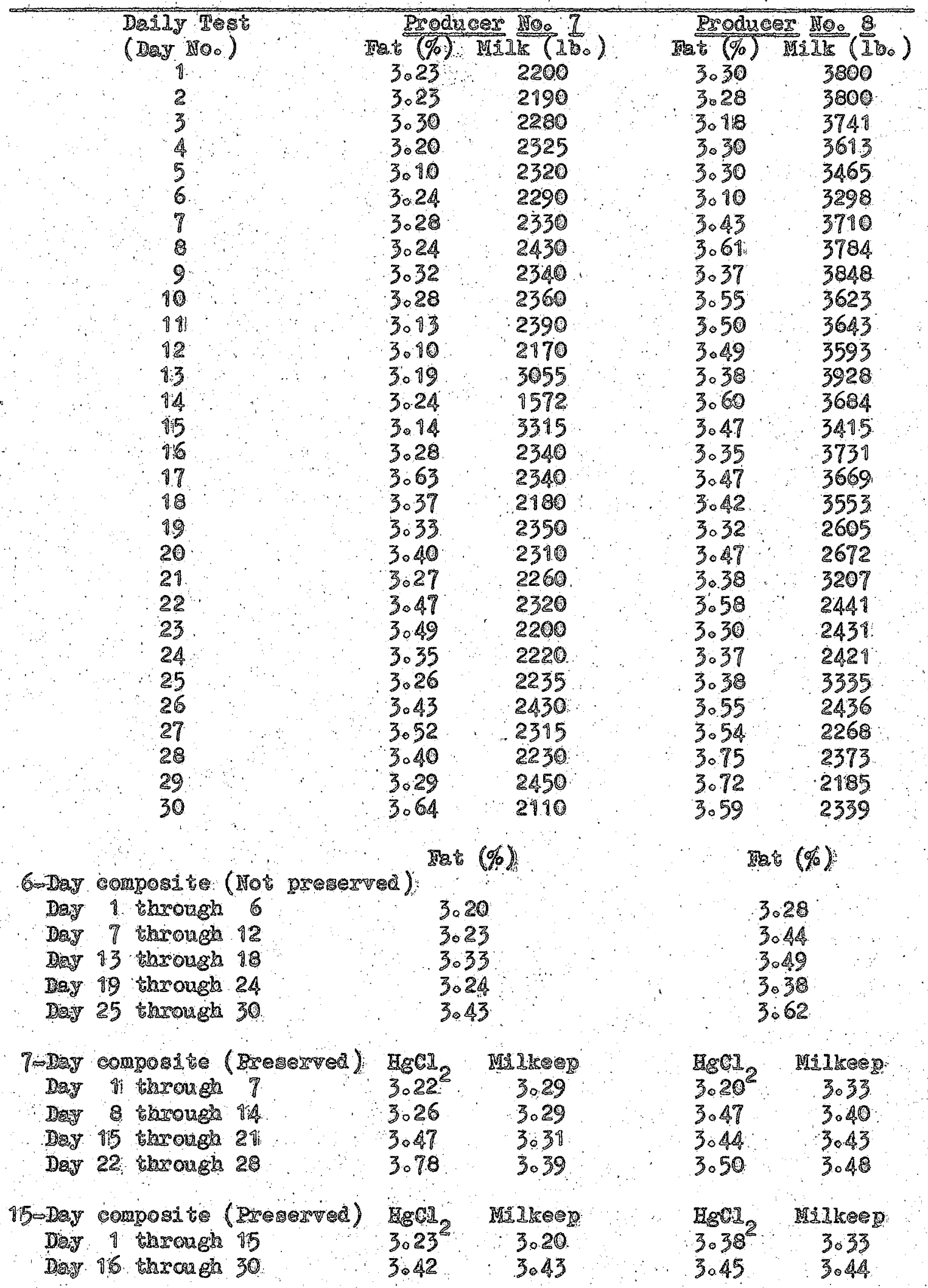




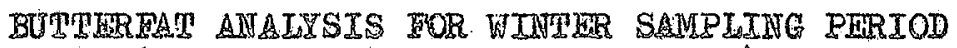

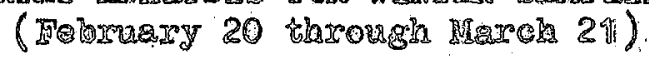

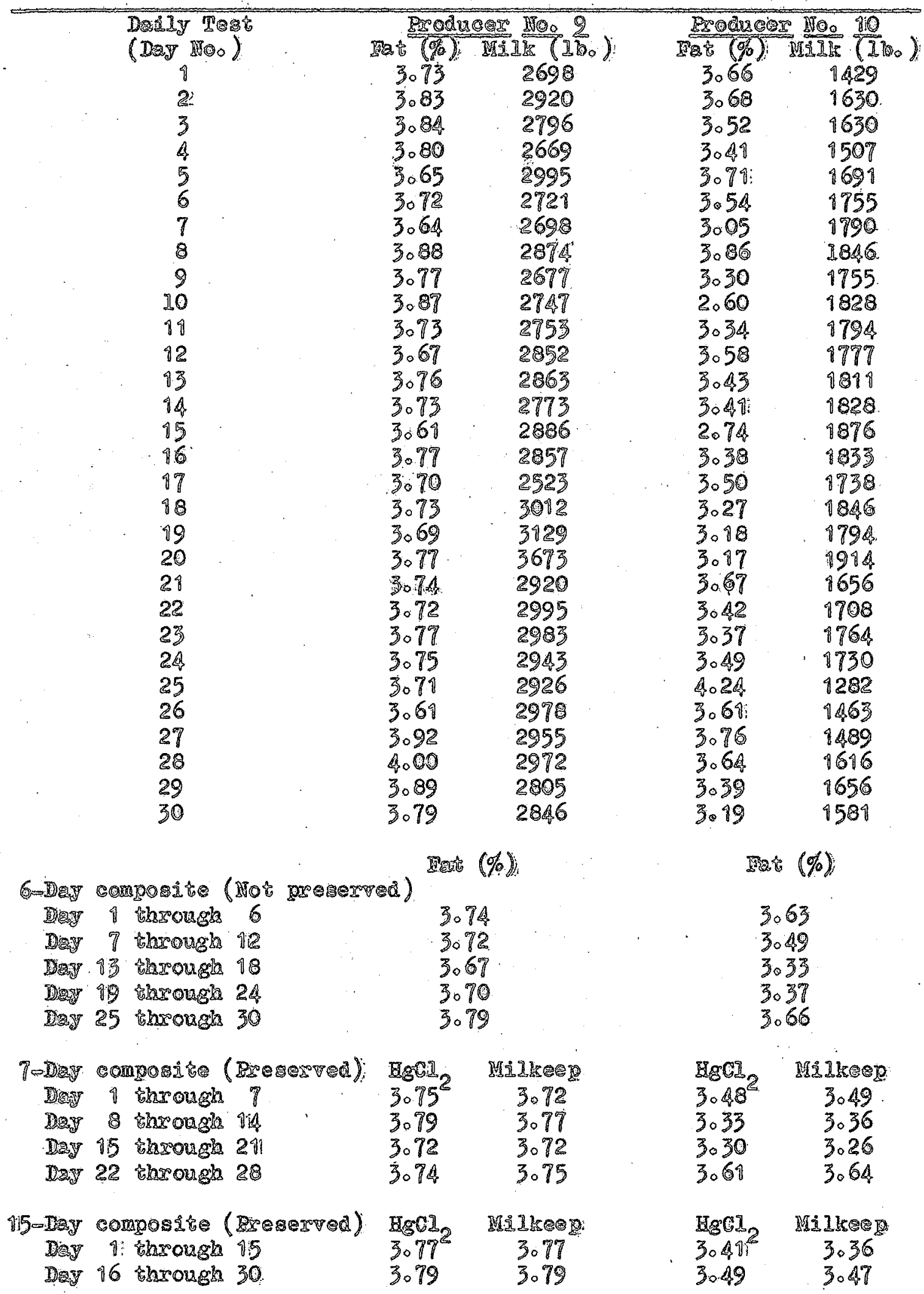




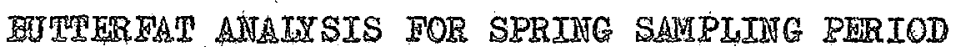

(Apris 14 ibrougla tray 13 ).

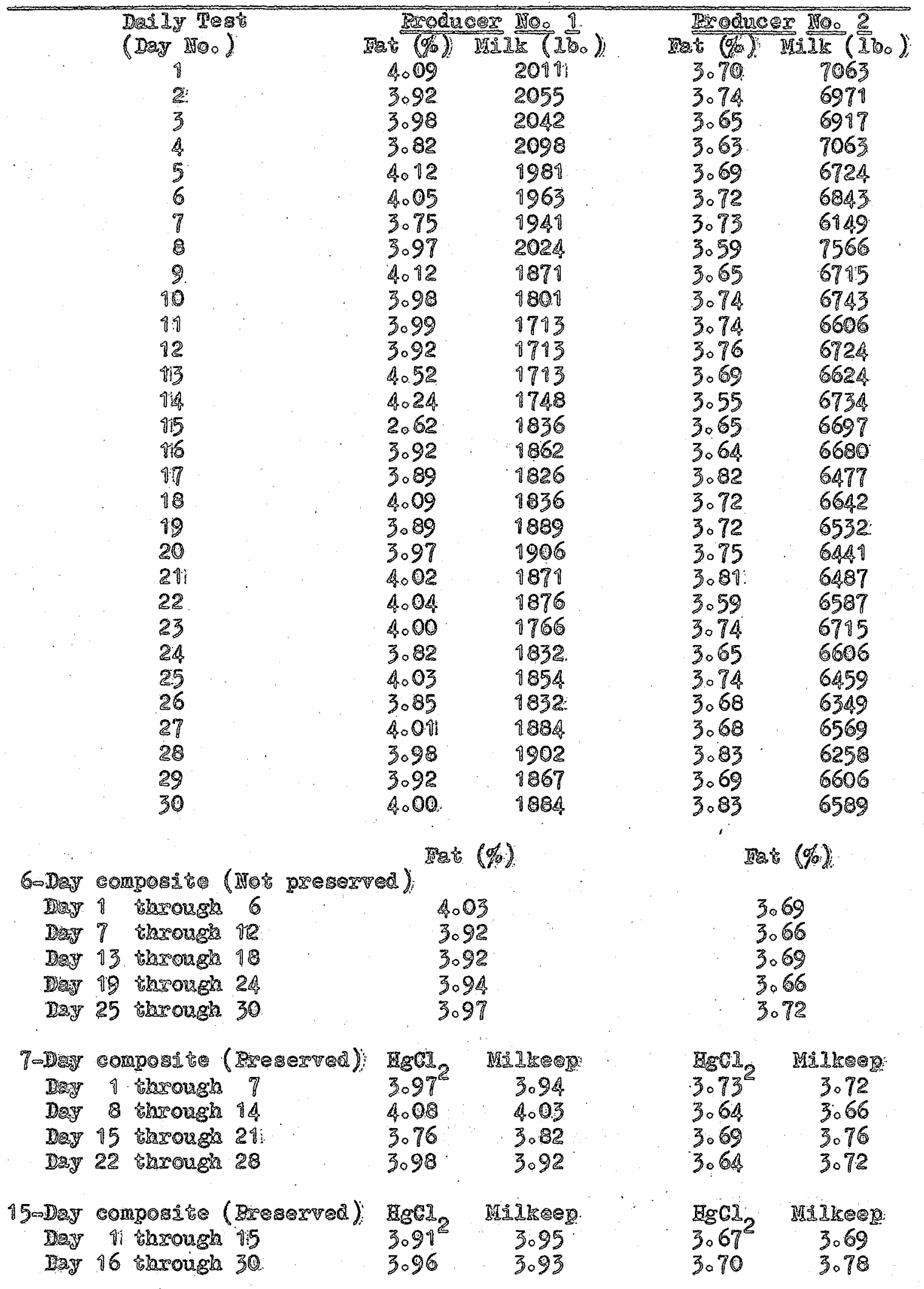


BUTRERFAT ANALYSIS FOR SPRING SAPIPUIYG PERIOD

(Aipris is through May 13):

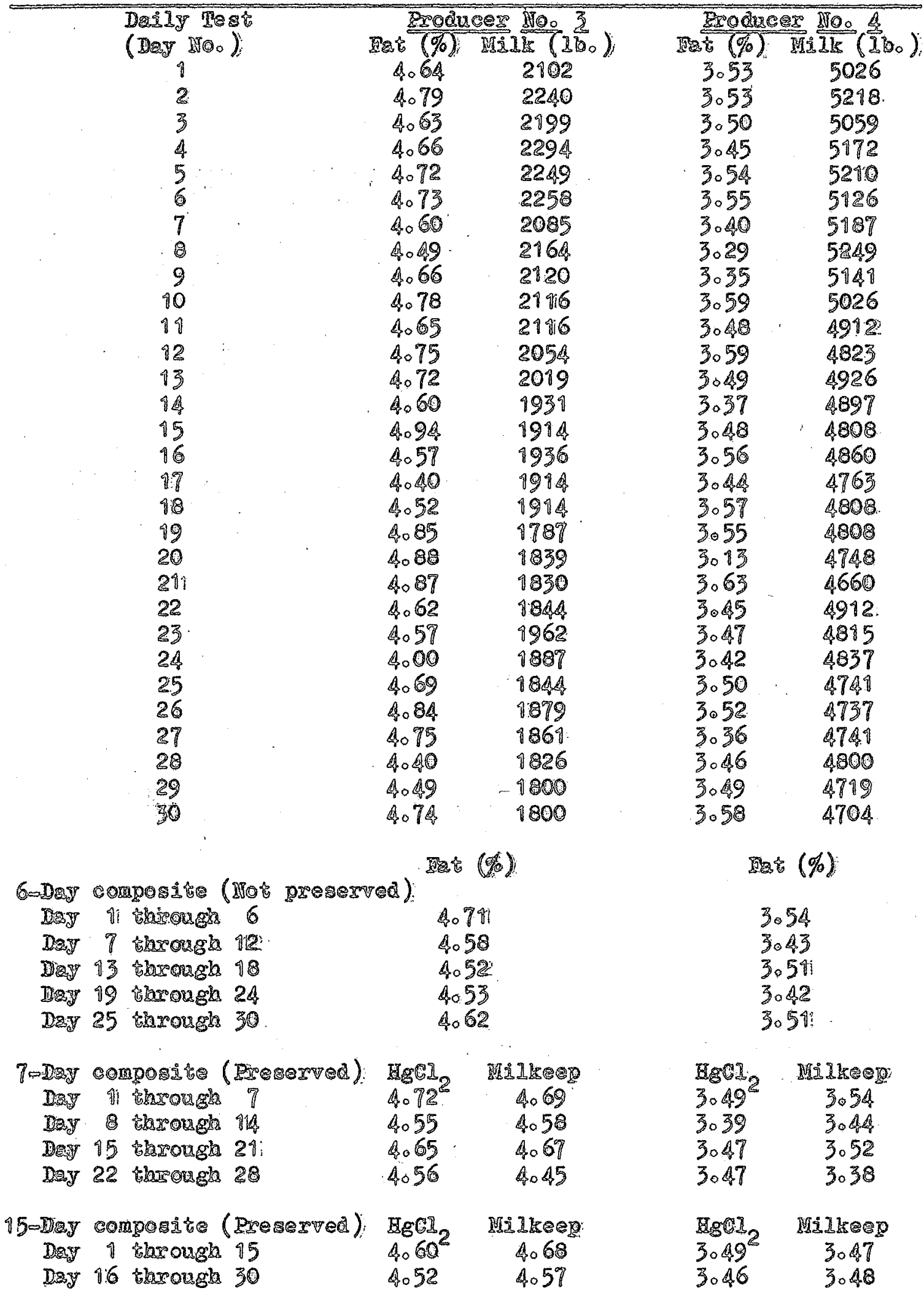


BUTRERTAT ANALYSIS FOR SPRIHT SAMPLIHG BERIOD

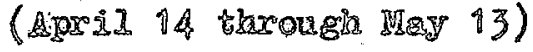

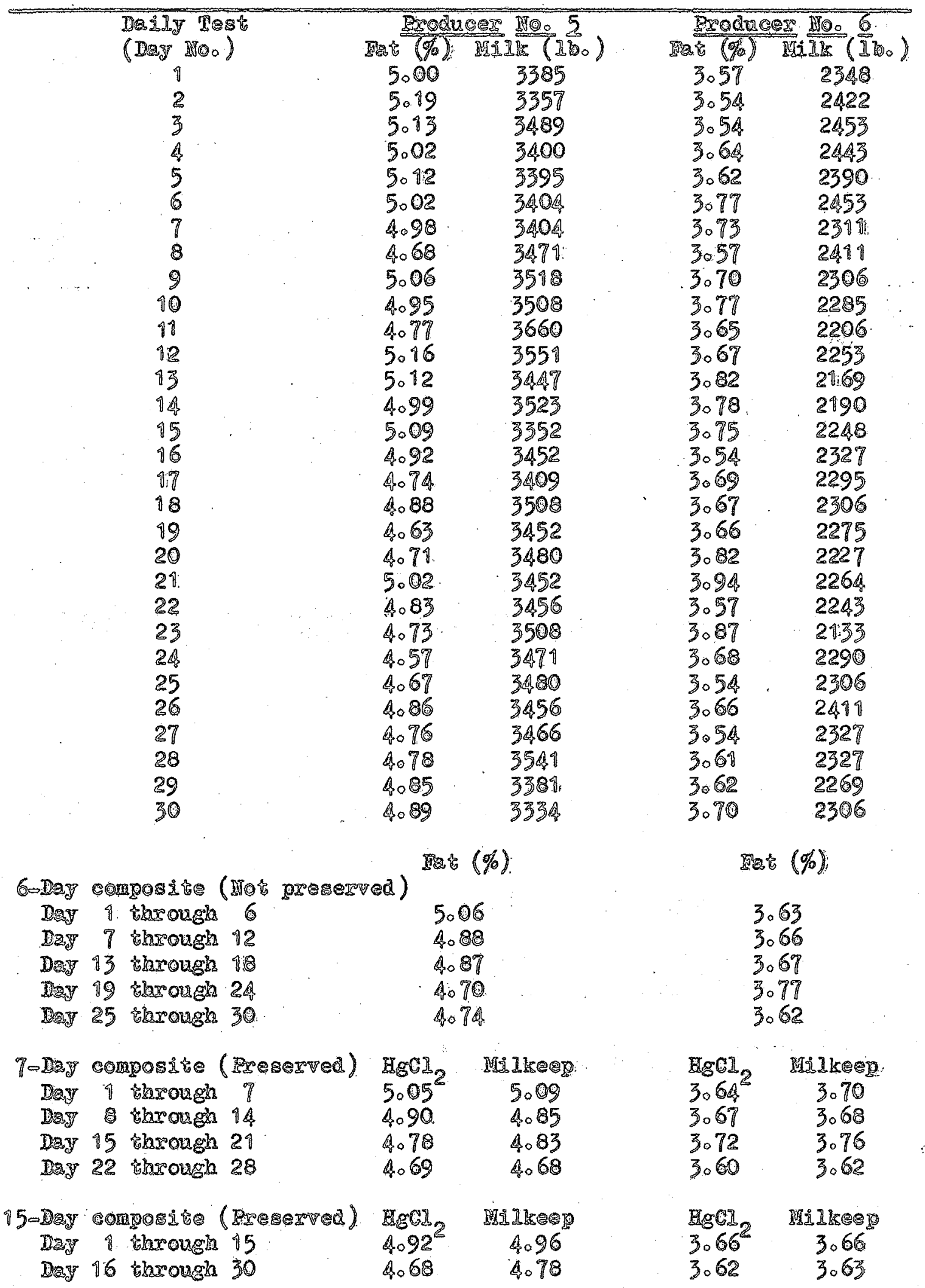


BORTERTAT ANATYSIS WOR SPRTHG SAMPITHTG PERTOD (Aproil 14 through May 13)

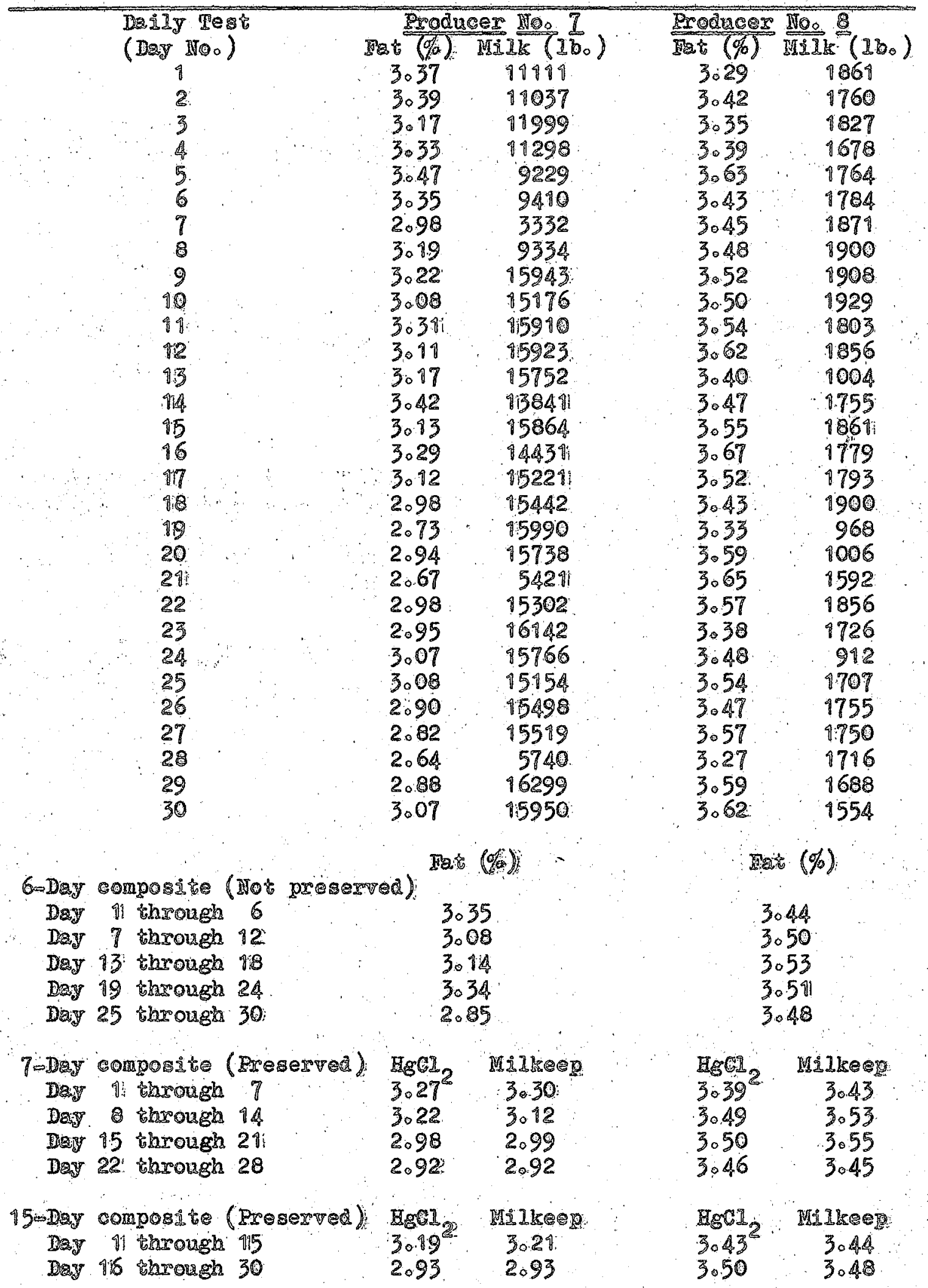




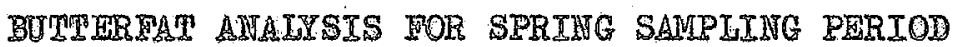

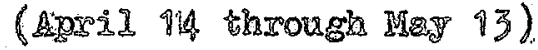

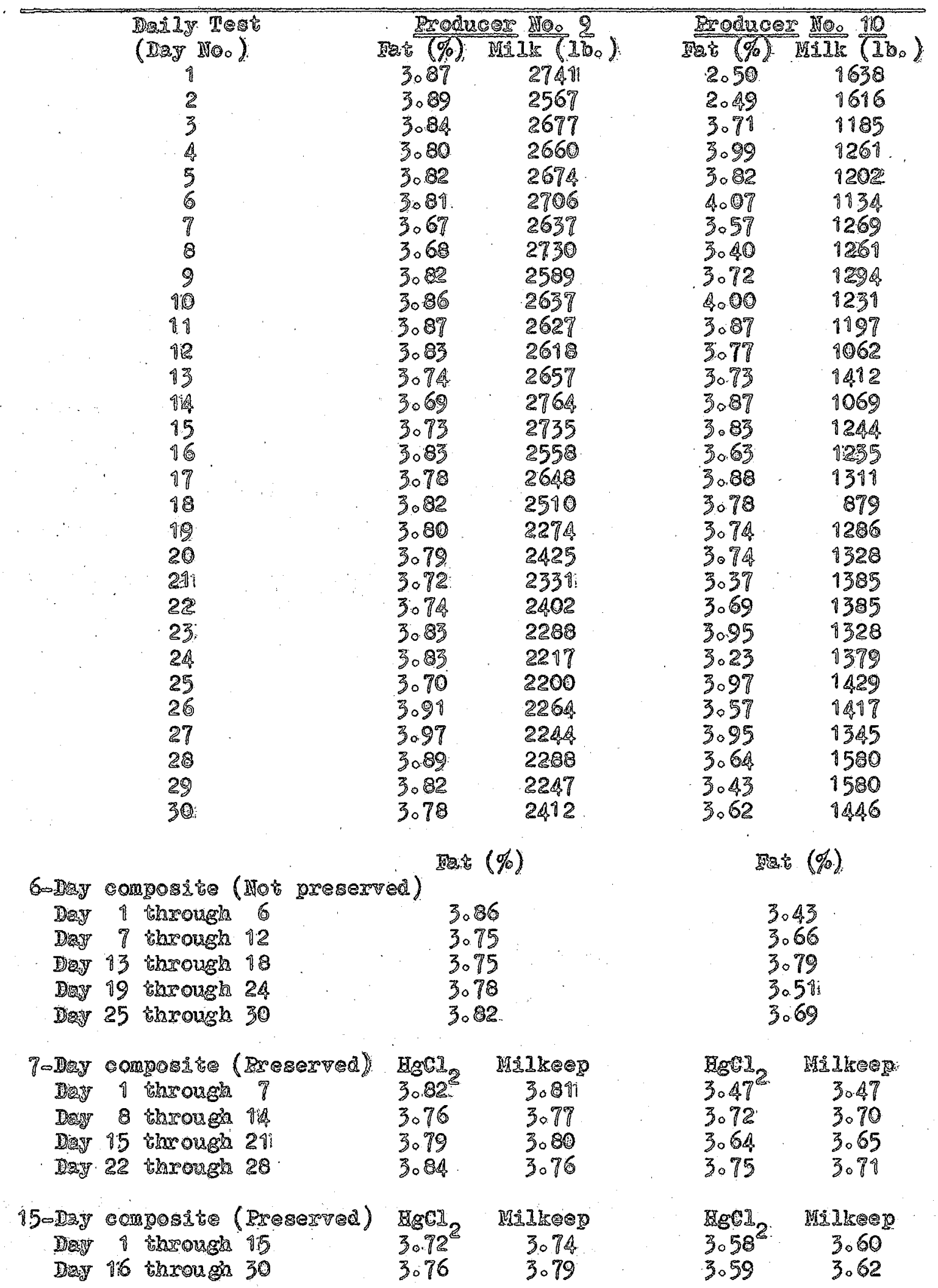


EJTHIRRAT ANLLYSIS FOR STMMER SAMPLINT RERIOD

(June 13 through $512.2 y$ 1.2)

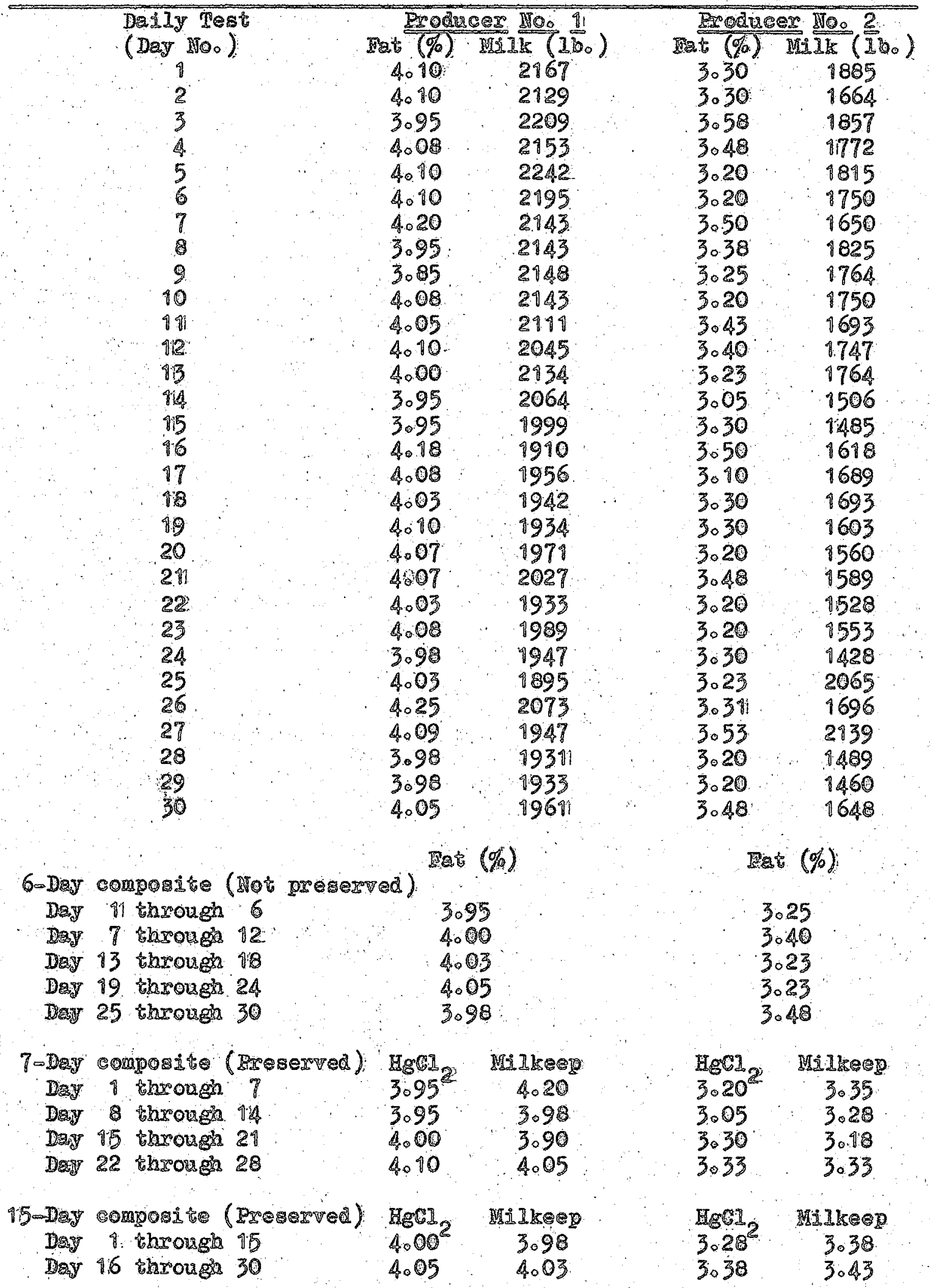




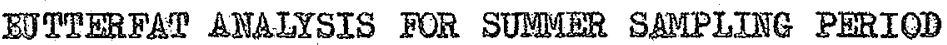

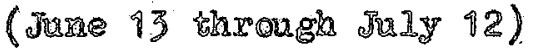

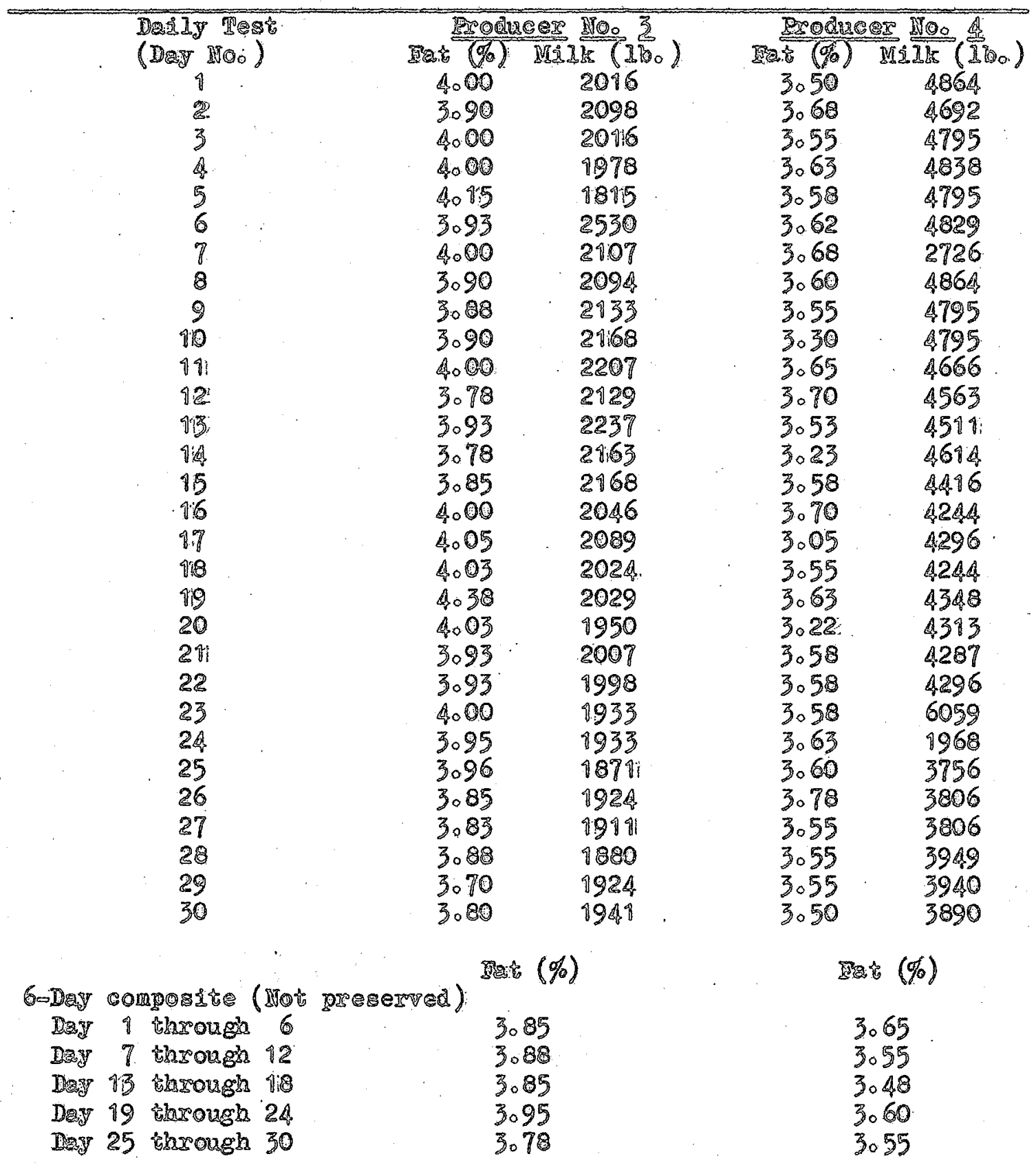

\begin{tabular}{|c|c|c|c|c|c|c|}
\hline $7=1.19 y$ & Composit & 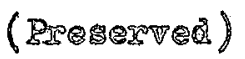 & $8 g C D_{2}$ & M I I & Hgen? & MIkeses \\
\hline Dasy & 1 tharough & 7 & $3080^{2}$ & 4010 & $3043^{2}$ & 3075 \\
\hline Dais & (8) trasongh & 84 & 3078 & 3093 & $3 \cdot 23$ & 3048 \\
\hline Das & 15 Glaxough & 21 & 4000 & 3095 & 3060 & 3.50 \\
\hline Day & 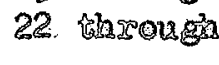 & 28 & 3080 & 3080 & 3058 & 3.58 \\
\hline 50 Dag & ampos: & (3reaerved) & $\mathrm{BgCl}$ & 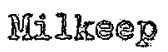 & $\mathrm{EgCl}_{2}$ & MIIK3: \\
\hline 008 & 1 through & 95 & $3.90^{\circ}$ & $3093^{\circ}$ & $3055^{2}$ & 3055 \\
\hline Day & 16 thIough & 30 & 3090 & 3090 & 3058 & 3058 \\
\hline
\end{tabular}




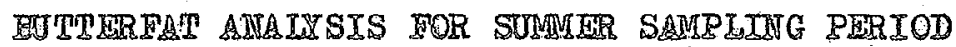

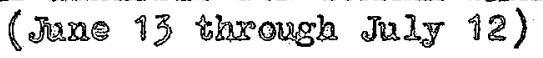

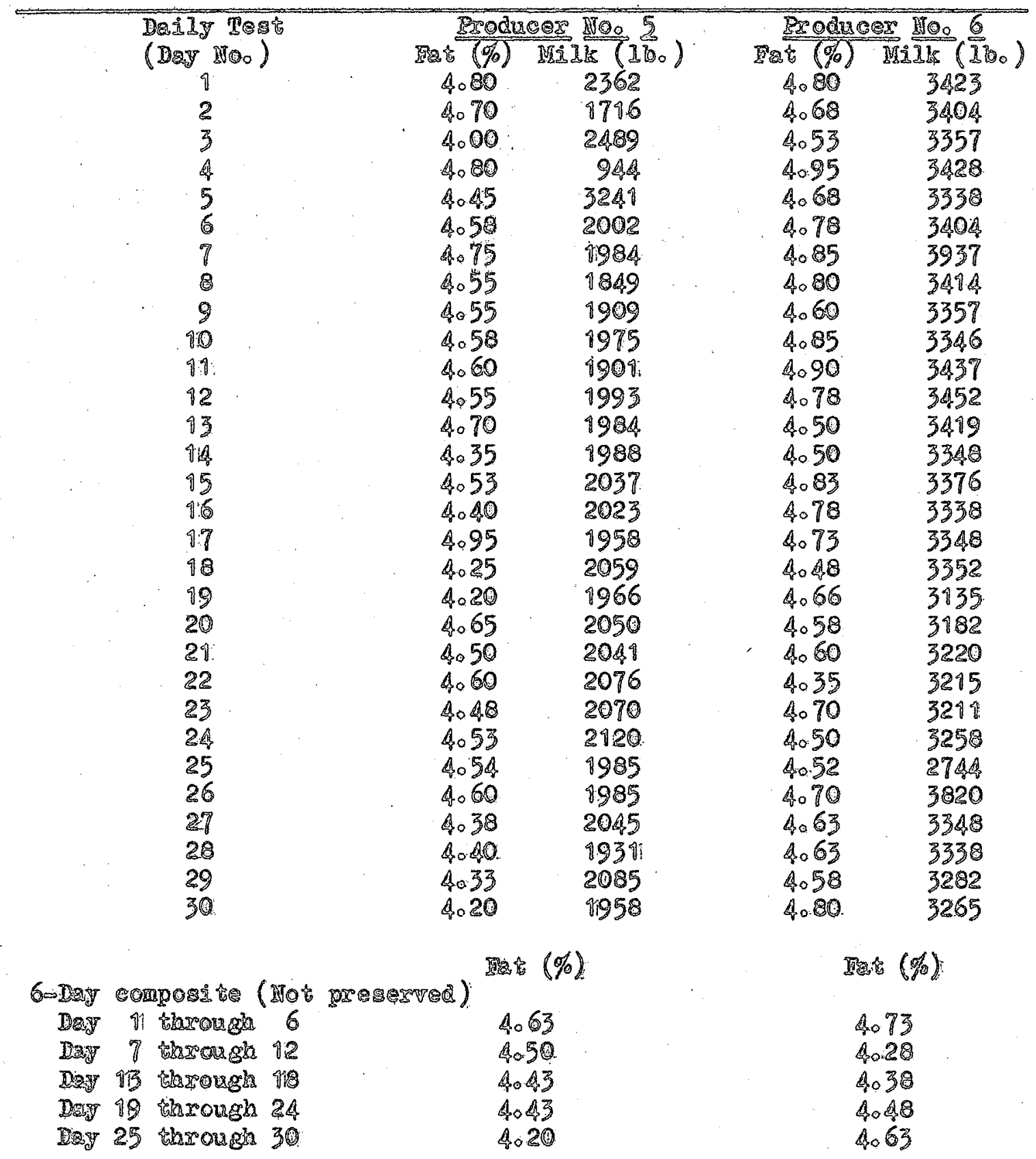

\begin{tabular}{|c|c|c|c|c|c|c|}
\hline $\begin{array}{l}\text { 7o Dagy } \\
\text { Day } \\
\text { Degy } \\
\text { Day } \\
\text { Digy }\end{array}$ & 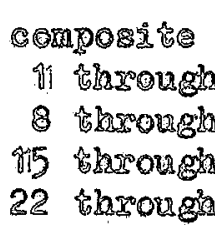 & $\begin{array}{l}\text { (Bireserved) } \\
77 \\
11.4 \\
21 \\
28\end{array}$ & $\begin{array}{l}8 g C 19 \\
4068^{25} \\
4035 \\
40.53 \\
4023\end{array}$ & $\begin{array}{l}\text { Madseep } \\
4.65 \\
4.55 \\
40.48 \\
4.25\end{array}$ & $\begin{array}{l}\text { Hge? } \\
4068^{2} \\
4.50 \\
4.50 \\
4.53\end{array}$ & 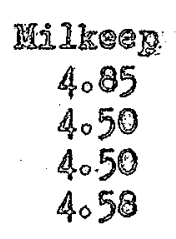 \\
\hline $\begin{array}{r}\text { 150.12y } \\
\text { Dagy } \\
\text { Dasy }\end{array}$ & $\begin{array}{l}\text { composite } \\
\text { 1! throug } \\
816 \text { through }\end{array}$ & $\begin{array}{l}\text { ( } 15 \text { seywed) } \\
15 \\
30\end{array}$ & $\begin{array}{l}9602 \\
40.60^{2} \\
4090\end{array}$ & 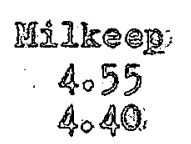 & $\begin{array}{l}B g C I_{2} \\
4 \circ 60^{2} \\
4060\end{array}$ & $\begin{array}{c}\text { MIneer: } \\
4062 \\
4065\end{array}$ \\
\hline
\end{tabular}


EUTRERFAT ANALXSIS FOR SUNMTR SANPIING PERIOD

(अvide 13 through Jaly 12 ):

\begin{tabular}{|c|c|c|c|c|c|c|}
\hline . & 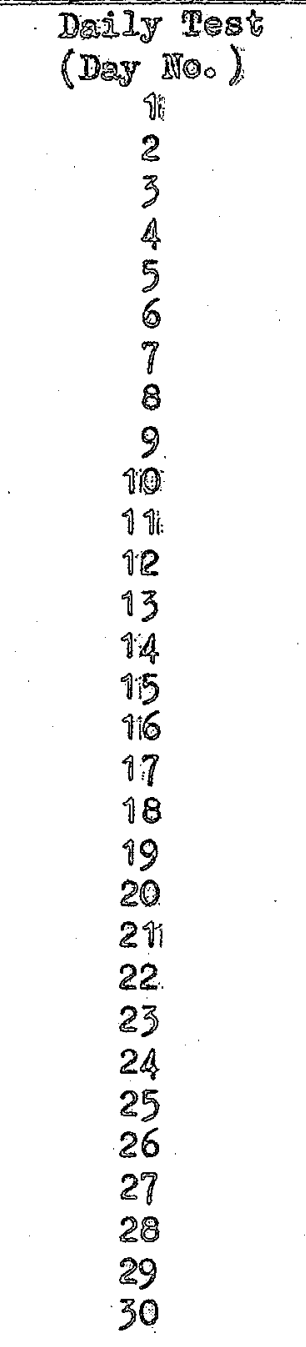 & 1 & 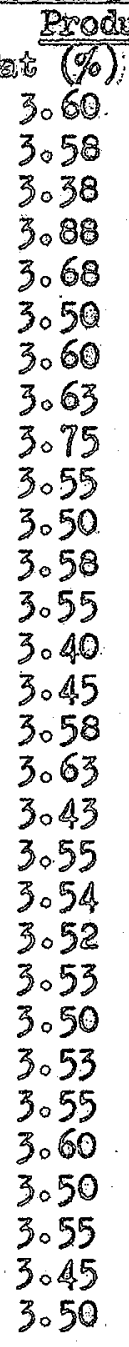 & 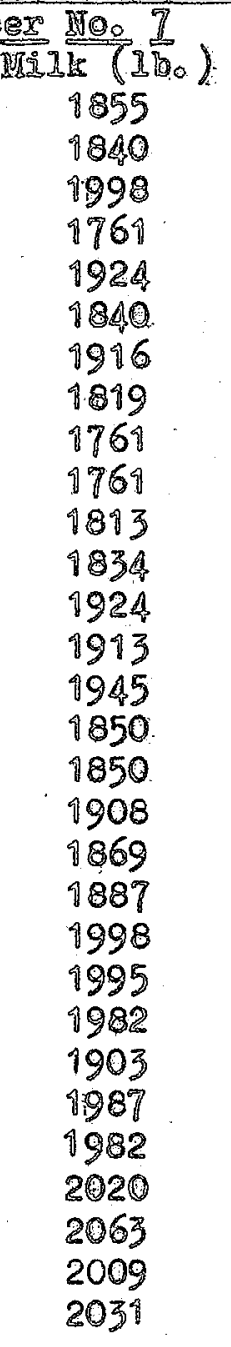 & 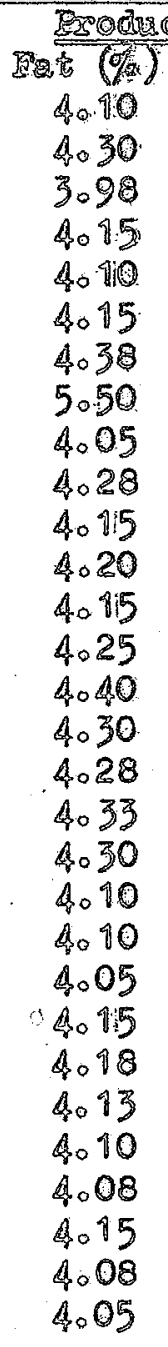 & 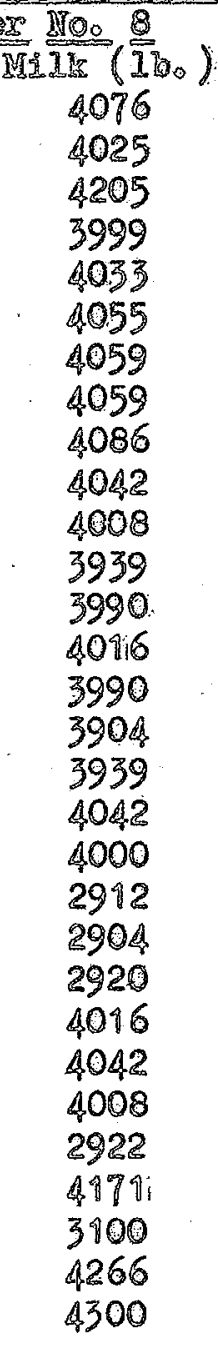 \\
\hline $\begin{array}{l}\text { 6o-Day } \\
\text { Doy } \\
\text { Day } \\
\text { Day } \\
\text { Day } \\
\text { Day }\end{array}$ & 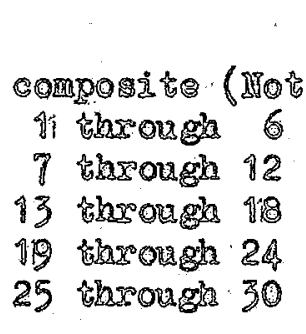 & \multicolumn{3}{|c|}{$\begin{array}{l}3060 \\
3058 \\
30.45 \\
3054 \\
3053\end{array}$} & \multicolumn{2}{|c|}{ 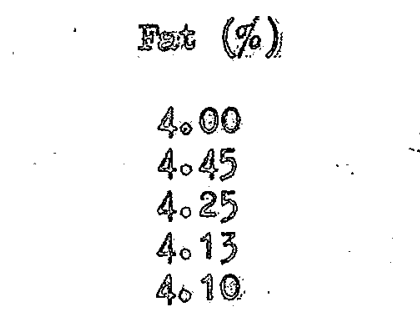 } \\
\hline $\begin{array}{l}\text { ToDesy } \\
\text { Day } \\
\text { Dey } \\
\text { Day } \\
\text { Day }\end{array}$ & 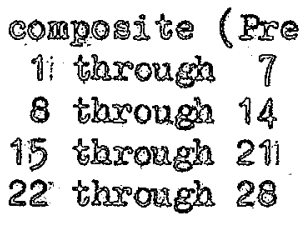 & sexved & $\begin{array}{l}\text { 여 } \\
3.60^{2} \\
30.40 \\
3.50 \\
3.50\end{array}$ & $\begin{array}{l}\text { 3.58: } \\
3.65 \\
3.60 \\
3.48 \\
3.55\end{array}$ & $\begin{array}{l}\text { EgG } \\
40115 \\
4025 \\
4030 \\
4.15\end{array}$ & $\begin{array}{c}\text { gifikeep } \\
4018 \\
40.43 \\
4010 \\
4005\end{array}$ \\
\hline $\begin{array}{r}\text { I50Dy } \\
\text { Dey } \\
\text { Day }\end{array}$ & 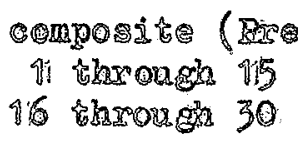 & serred) & $\begin{array}{l}5807 \\
3.58 \\
3.50\end{array}$ & $\begin{array}{l}\text { 125012. } \\
3068 \\
3048\end{array}$ & $\begin{array}{l}\operatorname{sg} 9{ }^{2} \\
4.28 \\
40.10\end{array}$ & $\begin{array}{c}\text { Malkepe } \\
4028 \\
4015\end{array}$ \\
\hline
\end{tabular}




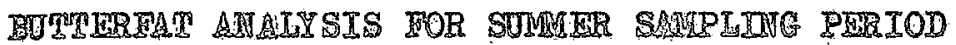

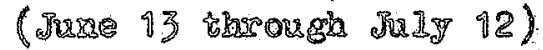

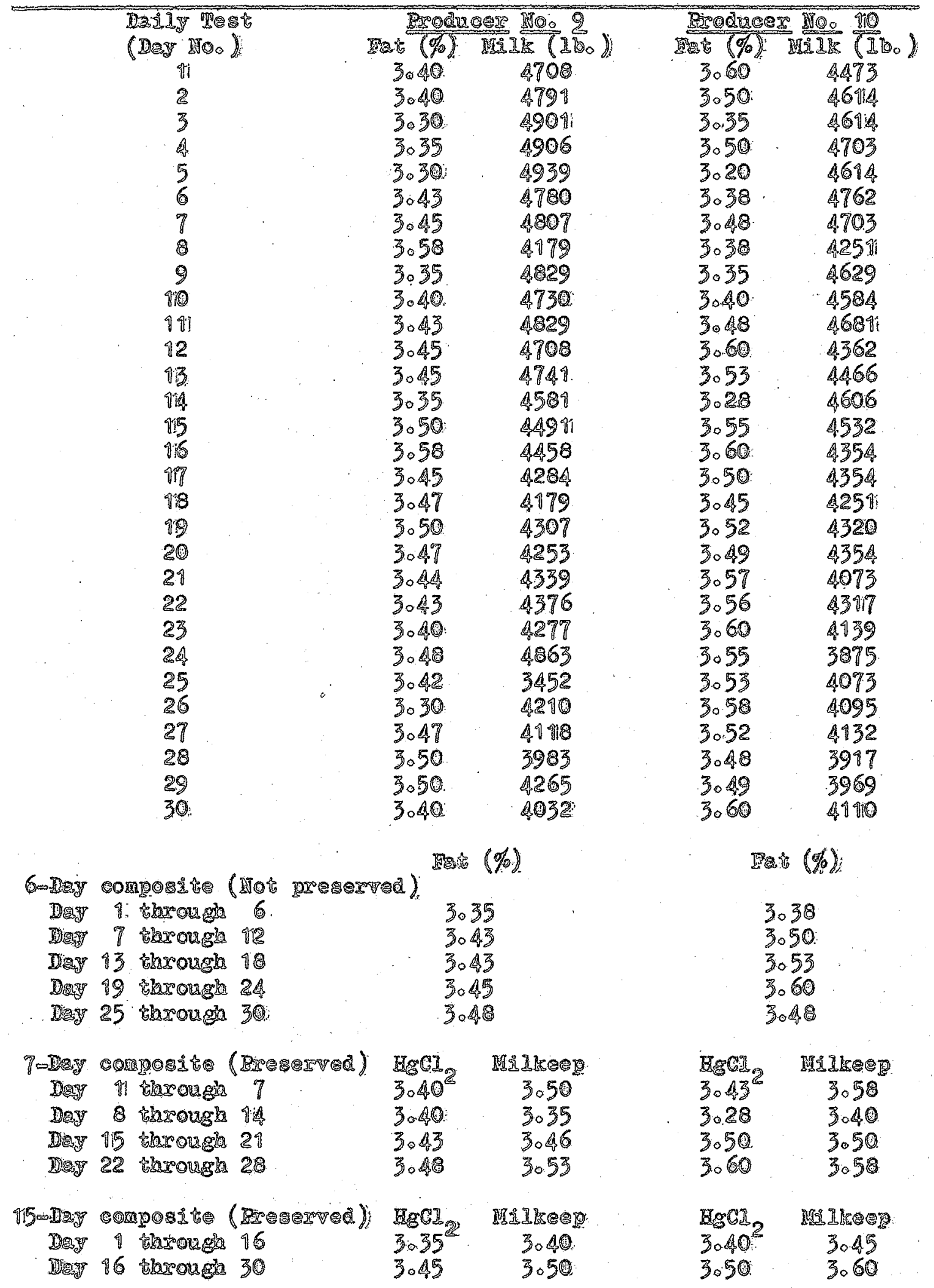

